\title{
Improved utilization of soybean meal through fermentation with commensal Shewanella sp. MR-7 in turbot (Scophthalmus maximus L.)
}

\author{
Chaoqun $\mathrm{Li}^{1,2}$, Beili Zhang ${ }^{1,2}$, Xin Wang ${ }^{4}$, Xionge $\mathrm{Pi}^{4}$, Xuan Wang ${ }^{1,2}$, Huihui Zhou ${ }^{1,2}$, Kangsen Mai ${ }^{1,2}$ \\ and Gen He $\mathrm{H}^{1,2,3^{*}}$
}

\begin{abstract}
Background: Increased inclusion of plant proteins in aquafeeds has become a common practice due to the high cost and limited supply of fish meal but generally leads to inferior growth performance and health problems of fish. Effective method is needed to improve the plant proteins utilization and eliminate their negative effects on fish. This study took a unique approach to improve the utilization of soybean meal (SBM) by fish through autochthonous plantdegrading microbe isolation and subsequent fermentation.

Results: A strain of Shewanella sp. MR-7 was isolated and identified as the leading microbe that could utilize SBM in the intestine of turbot. It was further optimized for SBM fermentation and able to improve the protein availability and degrade multiple anti-nutritional factors of SBM. The fishmeal was able to be replaced up to 45\% by Shewanella sp. MR-7 fermented SBM compared to only up to $30 \%$ by SBM in experimental diets without adverse effects on growth and feed utilization of turbot after feeding trials. Further analyses showed that Shewanella sp. MR-7 fermentation significantly counteracted the SBM-induced adverse effects by increasing digestive enzymes activities, suppressing inflammatory responses, and alleviating microbiota dysbiosis in the intestine of turbot.

Conclusions: This study demonstrated that plant protein utilization by fish could be significantly improved through pre-digestion with isolated plant-degrading host microbes. Further exploitation of autochthonous bacterial activities should be valuable for better performances of plant-based diets in aquaculture.
\end{abstract}

Keywords: Turbot, Shewanella sp. MR-7, Soybean meal, Fermentation, Intestinal health, Intestinal microbiota

\section{Background}

Mounting evidences during recent years have demonstrated the important roles of gut microbiota in host nutrient digestion, absorption, endocrine, metabolism and immune functions [1-3]. In particular, the genome

\footnotetext{
*Correspondence: hegen@ouc.edu.cn

${ }^{1}$ Key Laboratory of Aquaculture Nutrition and Feed, Ministry

of Agriculture, Ocean University of China, 5 Yushan Road,

Qingdao 266003, People's Republic of China

Full list of author information is available at the end of the article
}

of the gut microbiota (microbiome) provides additional metabolic capacities by contributing enzymes that are not encoded by the host genome and boost the host's ability of dietary utilization [4]. The gut microbiota also regulates diverse aspects of cellular differentiation and metabolic processes [5-7]. These microbiota-mediated functions are highly dependent on diet and their interplays [8], while the underlying mechanisms remain elusive. The critical roles that gut microbiota appear to play have spurred research to identify functional

(c) The Author(s) 2019. This article is licensed under a Creative Commons Attribution 4.0 International License, which permits use, sharing, adaptation, distribution and reproduction in any medium or format, as long as you give appropriate credit to the original author(s) and the source, provide a link to the Creative Commons licence, and indicate if changes were made. The images or other third party material in this article are included in the article's Creative Commons licence, unless indicated otherwise in a credit line to the material. If material is not included in the article's Creative Commons licence and your intended use is not permitted by statutory regulation or exceeds the permitted use, you will need to obtain permission directly from the copyright holder. To view a copy of this licence, visit http://creativeco mmons.org/licenses/by/4.0/. The Creative Commons Public Domain Dedication waiver (http://creativecommons.org/publicdomain/ zero/1.0/) applies to the data made available in this article, unless otherwise stated in a credit line to the data. 
microorganisms and their associated metabolism of dietary components.

Compared to those of terrestrial animals, the gut microbiota of fish and its functional significance are far less understood. It is known that the gut microbiota of aquatic animals is unique in many aspects. In contrast to that of human and terrestrial animals dominated by Gram-positive anaerobes, the microbial composition in the digestive tract of fish and shellfish is prevailed by Gram-negative facultative anaerobes [9]. Furthermore, the activities of microbiota in aquatic animals are greatly influenced by environmental factors such as temperature, salinity, water quality, etc. [10-12]. It is established that gut microbiota plays a key role in digestion and assimilation of terrestrial animals [13]. Similarly, the microorganisms harbored in aquatic animals may also make significant contributions to host digestion [14].

Increased inclusion of plant proteins in aquafeeds has become a common practice because of the high cost and limited supply of fishmeal $[15,16]$. However, over-substitution of fishmeal with plant proteins generally leads to reduced digestion, enteritis, and inferior growth performance of fish especially carnivorous fish [17-19]. It is known that fish harbor a variety of proteolytic, amylolytic and cellulolytic bacteria [20]. However, the correlations between the host ability of plant protein utilization and the autochthonous microbes have never been well established. Better understanding the specific effects of particular autochthonous microbes and their contributions to the utilization of alternative protein sources will improve our ability to manipulate and fortify fish gut microbial communities to enhance the aquaculture productivity.

In the present study, turbot (Scophthalmus maximus L.), an economically valuable marine carnivorous fish with high protein requirement and sensitivity to protein sources [21], was chosen as the model species. We isolated microbes from the intestinal mucosa of the turbot (Scophthalmus maximus L.) through directional enrichment using soybean meal based medium. A strain of Shewanella sp. MR-7 was identified and its effects on soybean meal fermentation and subsequent dietary utilization by turbot were evaluated. To our knowledge, this approach has been rarely conducted.

\section{Results}

Isolation and identification of Shewanella sp. MR-7 as the leading SBM-degrading bacteria in turbot intestine The microbiota of turbot intestine was first characterized and shown in Additional file 1: Figure S1. The SBM-degrading bacteria were enriched by culturing the isolates of turbot intestinal mucosa in the SBM liquid medium. After the culture was further inoculated onto casein agar, bacterial colonies with clear zones
$>4 \mathrm{~cm}$ were selected and purified by dilution streaking method for further identification by $16 \mathrm{~S}$ rDNA sequencing. Among the bacteria identified, Shewanella sp. MR-7 showed the best SBM degradation ability.

The genome of Shewanella sp. MR-7 had a length of 4,077,231 bp and contains 4530 predicted genes with a $\mathrm{G}+\mathrm{C}$ content of $48.88 \%$ (Table 1). 3709 predicted genes had COG function annotation (Fig. 1). Detailed information of the COG function annotation including genes encoding various enzymes was shown in Additional file 2: Table S2. The blast results were annotated in the GO database by blast2go and GO function annotation including cellular components, molecular functions and biological processes (Fig. 2). Moreover, 2482 predicted genes were identified to be possibly involved in 40 KEGG pathways that were classified into "metabolism", "genetic information processing", "cellular processes", "environmental information processing" "organismal systems" etc. Among 1223 genes associated with "metabolism", 190 genes were involved in carbohydrate metabolism and 189 genes were involved in amino acid metabolism (Fig. 3, Additional file 3: Table S3). Moreover, among 62 genes associated with lipid metabolism, 33 genes were involved in fatty acid (such as linoleic acid, arachidonic acid and alpha-linolenic acid) metabolism (Additional file 4: Table S4).

\section{Parameter optimization and characterization of Shewanella sp. MR-7}

The growth of Shewanella sp. MR-7 under different temperature and $\mathrm{pH}$ was evaluated. Examined by its growth curve (Fig. 4a), the optimal growth temperature and $\mathrm{pH}$ for Shewanella sp. MR-7 was $37{ }^{\circ} \mathrm{C}$ and pH 6.0 respectively. The temperature and $\mathrm{pH}$ of optimal protease production by Shewanella sp. MR-7 were at $37^{\circ} \mathrm{C}$ and pH 6.0 respectively (Fig. 4b). Under optimized condition, Shewanella sp. MR-7 showed secretion of several enzymes including protease $\left(380.54 \pm 0.39 \mathrm{U} \mathrm{L}^{-1}\right)$, pectinase $\left(18.49 \pm 0.41 \mathrm{U} \mathrm{L}^{-1}\right)$, cellulase $\left(39.11 \pm 1.23 \mathrm{U} \mathrm{L}^{-1}\right)$, hemicellulase $(93.86 \pm 0.72$ $\left.\mathrm{U} \mathrm{L}^{-1}\right)$ and phytase $\left(14.80 \pm 0.40 \mathrm{U} \mathrm{L}^{-1}\right)$.

\section{Table 1 Features of Shewanella sp. MR-7 genome}

\begin{tabular}{ll}
\hline Attributes & Values \\
\hline Gene number & 4530 \\
Gene total length & $4,077,231 \mathrm{bp}$ \\
Gene average length & $900.05 \mathrm{bp}$ \\
Gene density & 0.96 genes per kb \\
GC content in gene region (\%) & 48.88 \\
Gene/Genome (\%) & 85.97 \\
Intergenetic region length & $665,189 \mathrm{bp}$ \\
GC content in intergenetic region (\%) & 41.75 \\
Intergenetic length/Genome (\%) & 14.03 \\
\hline
\end{tabular}




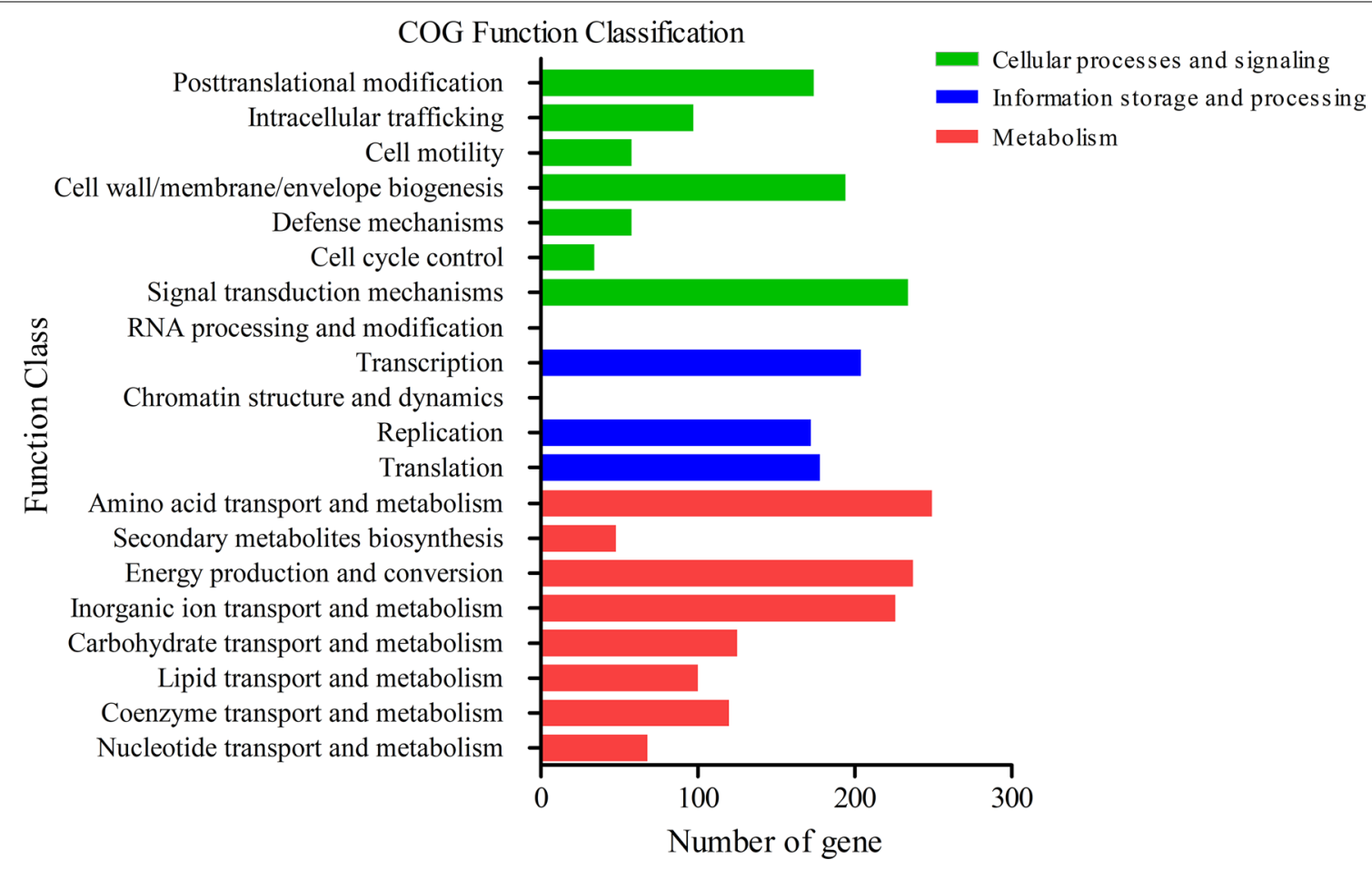

Fig. 1 COG function classification of Shewanella sp. MR-7

Measured by the trichloroacetic acid soluble nitrogen (TCA-N) level (Fig. 4c), the optimal parameters of soybean meal fermentation by Shewanella sp. MR-7 were: initial moisture content at $100 \%$, inoculum concentration at $10 \%$ and incubation temperature at $37^{\circ} \mathrm{C}$. Although the TCA-N production continued to increase, the possibility of contamination and unpleasant ammonia odor rose when the fermentation exceeded $60 \mathrm{~h}$. Therefore, we kept the fermentation period at $48 \mathrm{~h}$ for further experiments. Under the optimized parameters, the Shewanella sp. MR-7 fermented soybean meal significantly increased the crude protein at $3.20 \pm 0.42 \%$, TCA-N at $482.79 \pm 0.95 \%$ and decreased crude lipid at $21.66 \pm 2.27 \%$ (Table 2). The levels of raffinose and stachyose were decreased by $29.25 \pm 1.28 \%$ and $24.25 \pm 1.84 \%$ respectively. The levels of anti-nutritional factors including trypsin inhibitors, glycinin and $\beta$-conglycinin were significantly decreased by $90.19 \pm 0.42 \%, \quad 77.36 \pm 0.14 \%$ and $84.52 \pm 0.18 \%$ respectively $(P<0.05)$. The digestion abilities of SBM crude protein and ANFs by Shewanella sp. MR-7 and other representative strains from references were compared (Additional file 5: Table S5).

\section{Dietary FSBM improved the growth performance and feed utilization of turbot}

The performances of fermented soybean meal in the turbot diet were evaluated by a 79-day feeding trial. As shown in Table 3, no significant differences $(P>0.05)$ were found in the final body weight (FBW), specific growth rate (SGR), and weight gain rate (WGR) among groups fed with either FM diet, or diets with fishmeal levels replaced by SBM up to $30 \%$, or by FSBM up to $45 \%$, while all these parameters were decreased significantly in groups with higher dietary fishmeal substitution levels. The survival rate (SR) showed no significant differences among different groups $(P>0.05)$. In addition, feed intake (FI) showed no significant differences among all groups except a significant increase was found in the FSBM60 group $(P<0.05)$. The protein efficiency ratio $(\mathrm{PER})$ and feed efficiency ratio (FER), as well as the apparent digestibility coefficients (ADC) of dry matter and crude protein, showed no significant reduction $(P>0.05)$ when the dietary fishmeal was replaced by SBM up to $30 \%$ and FBSM up to $45 \%$, but reduced significantly beyond these substitution levels $(P<0.05)$.

\section{Dietary FSBM increased the intestinal digestive enzyme activities}

As shown in Table 4, compared to that of the FM group, the trypsin activity was decreased significantly when the dietary fishmeal substitution by $\mathrm{SBM} \geq 30 \%$ or by FSBM $\geq 60 \%(P<0.05)$. The lipase activity increased in FSBM15 and FSBM 30 groups or remained similar in FSBM45 and FSBM60 groups, but decreased significantly 


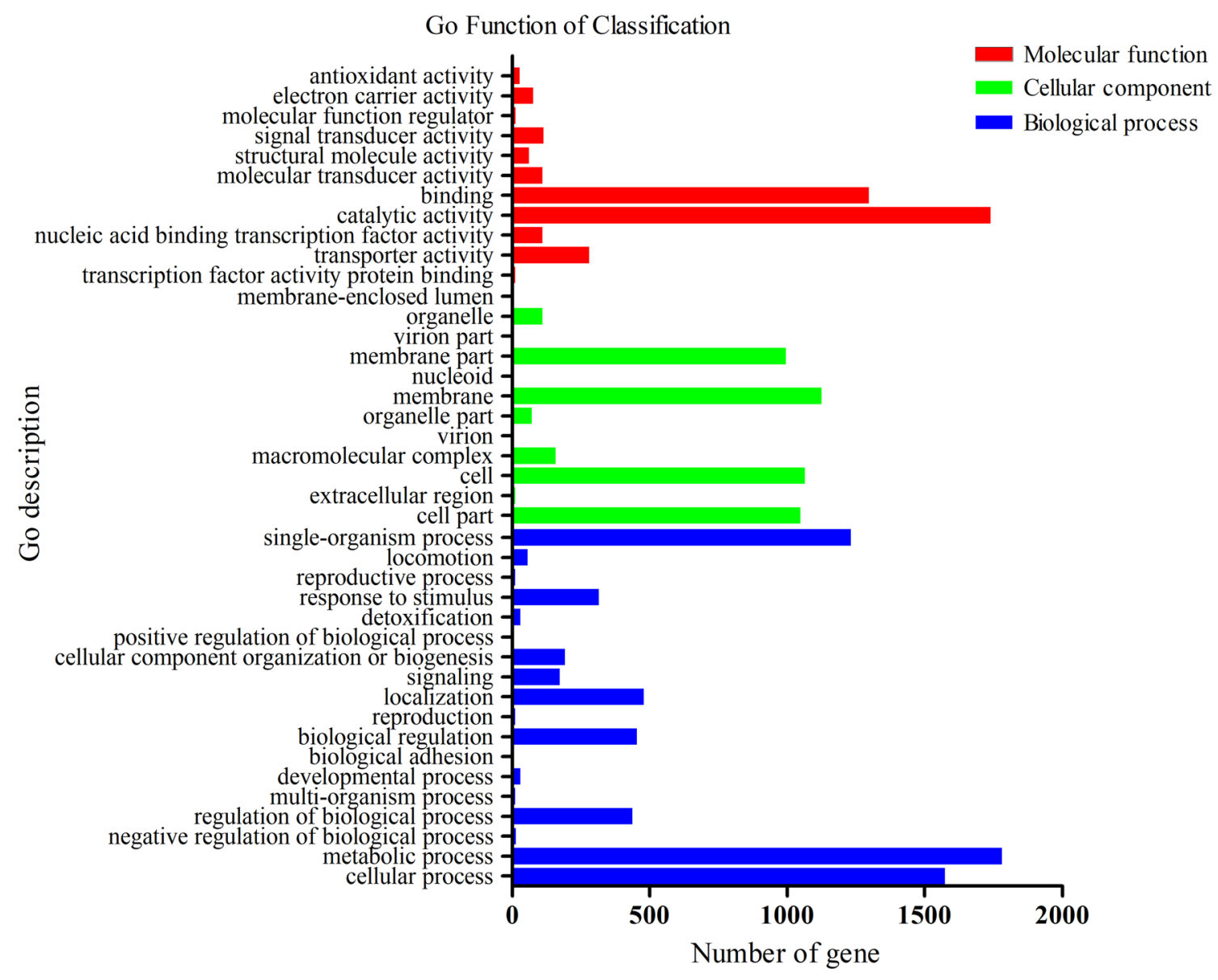

Fig. 2 GO function annotation of Shewanella sp. MR-7

in all SBM groups, when compared to that of the FM group. The intestinal diastase activity of turbot showed no significant differences among groups except significant reductions in SBM45 and SBM60 groups.

\section{Dietary FSBM suppressed the intestinal inflammation and enhanced the intestinal integrity}

As shown in Fig. 5a, with the increases of fishmeal replacement by SBM, the height and number of mucosal folds were reduced in the distal intestine. The length of microvilli was also decreased steadily with the increased inclusion of SBM levels. However, no significant morphological changes were observed in the distal intestines of FSBM groups compared with those of the FM group. Furthermore, the expression levels of tight junction genes of occludin, ZO-1 transcript variant 1 and tricellulin were significantly reduced in SBM groups with dietary fishmeal replacement $\geq 30 \%$, $\geq 45 \%$, $\geq 45 \%$ respectively (Fig. 5b). However, the expression levels of these genes were only reduced in FSBM groups with dietary fishmeal replacement $\geq 60 \%$ (Fig. $5 \mathrm{~b}$ ). In addition, the expression levels of pro-inflammatory (IL-1 $\beta$ and TNF- $\alpha$ ) and antiinflammatory (TGF- $\beta 1$ ) cytokines were significantly increased or decreased respectively in SBM groups with dietary fishmeal replacement $\geq 45 \%$ (Fig. 5c). However, only the expression levels of prof-inflammatory cytokines in FSBM60 showed increases among the FSBM groups, while that of the TGF- $\beta 1$ remained stable among all the FSBM groups. The expression level of MUC-2, the major secretory mucin and biomarker of intestine inflammation [22] was increased significantly in SBM groups with dietary fishmeal replacement $\geq 30 \%$, while only that of FSBM60 showed significant increase in fermented groups (Fig. 5c).

\section{Fermentation alleviated SBM induced intestine microbiota dysbiosis}

To analyze the possible intestine microbiome changes, we select the FM, SBM45 and FSM45 as the representative experimental groups for detailed examinations. After sequence quality control and feature filtering, a total number of 650,776 clean reads were generated, covering 


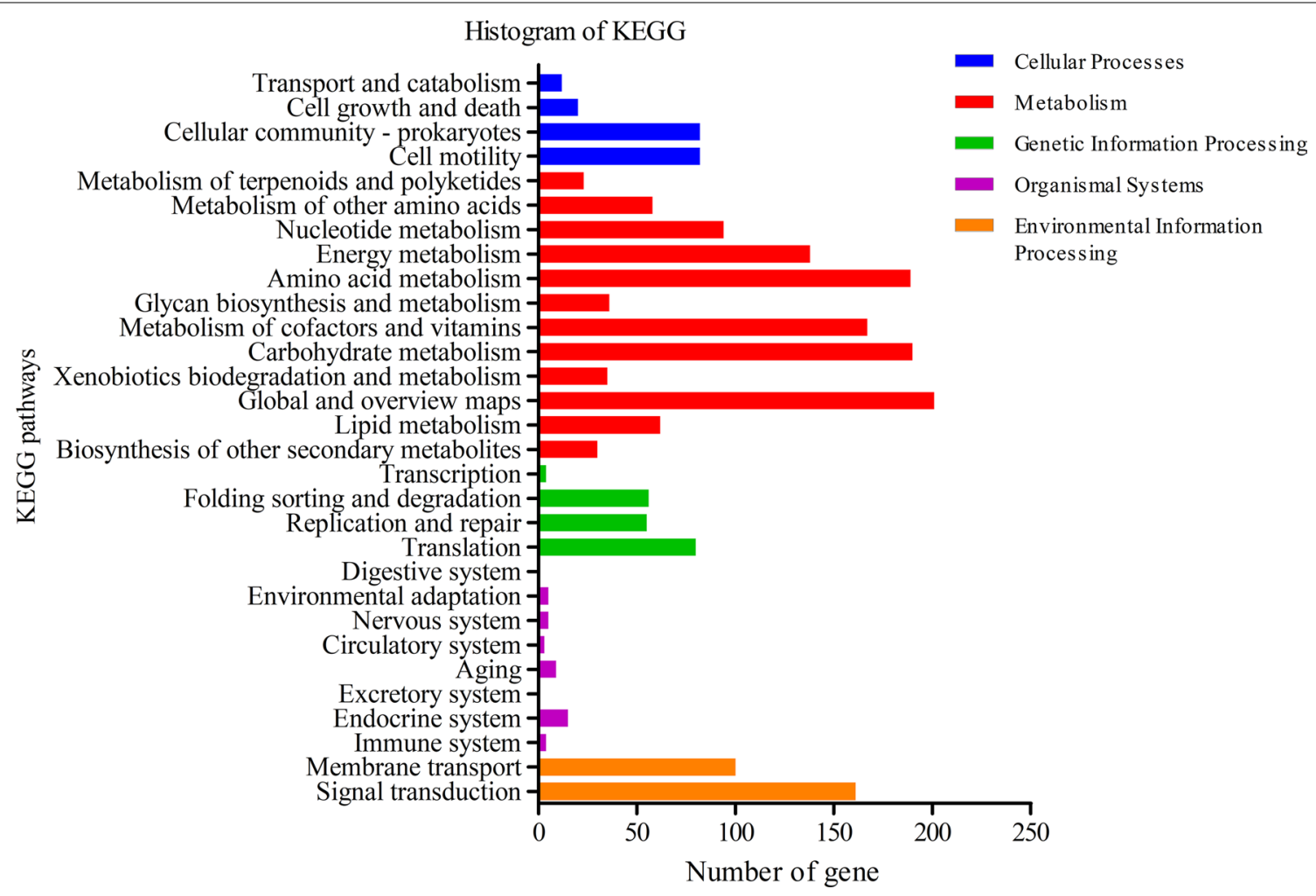

Fig. 3 KEGG function classification of Shewanella sp. MR-7

5437 OTUs (97\% similarity level) from 9 samples in FM, SBM45 and FSBM45 groups. The rarefaction curves for observed species number tended to approach the saturation plateau, indicating adequate sequencing depth for all samples (Additional file 5: Figure S2). A Venn diagram showed that 489 OTUs were shared by FM, SBM45 and FSBM45 groups, and the number of unique OTUs in group FM, SBM45 and FSBM45 was 104, 391 and 599, respectively (Fig. 6a). The changes of bacterial richness (expressed by Chao1 and ACE) and diversity (expressed by Shannon and Simpson) in response to FM, SBM45 and FSBM45 were shown in Table 5. The Chao1 index and ACE index were significantly increased in FSBM45 compared to those of FM and SBM45 groups $(P<0.05)$. The alpha-diversity indicated by Shannon index and Simpson index were significantly increased in FSBM45 and SBM45 compared to that of FM $(P<0.05)$. Moreover, the PCoA plot showed clear clusters of microbial samples from different treatments, indicating a different response model of intestinal microbiota to various diets (Fig. 6b). The FSBM clusters were found to be more coherent with FM clusters than SBM clusters (Fig. 6b).

As shown in Fig. 6c and Additional file 6: Table S6, the intestine mucosal microbiota of FM and FSBM45 were dominated by Firmicutes (72.86\%, 62.56\%). However, the intestine mucosal microbiota of SBM45 were dominated by Bacteroidetes (46.20\%), followed by Firmicutes (35.581\%). Compared with FM, dietary SBM significantly reduced the relative abundances of Firmicutes by more than 2 times $(P<0.05)$ and increased the relative abundance of Bacteroidetes by more than 25 times $(P<0.05)$. However, Shewanella sp. MR-7 fermentation alleviated these SBM-induced changes and showed more similarity to bacterial composition of FM group. At genus level, Lactococcus, Bacillus, Bacteroides, Lactobacillus, Prevotellaceae, Photobacterium, Enterobacteriaceae, Lachnoclostridium, Sutterella and Alloprevotella formed the top ten dominant genera, and their relative abundances were significantly influenced by dietary treatment $(P<0.05)$ (Fig. 6d and Additional file 7: Table S7). Lactococcus was accounted for $44.19 \%$ of the total bacterial population in FM, followed by Lactobacillus (26.01\%). Bacillus was accounted for $28.57 \%$ of the total bacterial population in FSBM, followed by Lactococcus (9.08\%). Bacteroides was accounted for $18.88 \%$ of the total bacterial population in SBM, followed by Prevotellaceae $(9.08 \pm 0.59 \%)$. Dietary SBM significantly increased the relative abundances of Bacteroides, Prevotellaceae, Enterobacteriaceae and significantly reduced the relative abundances of Lactococcus and Lactobacillus compared to those of control. 

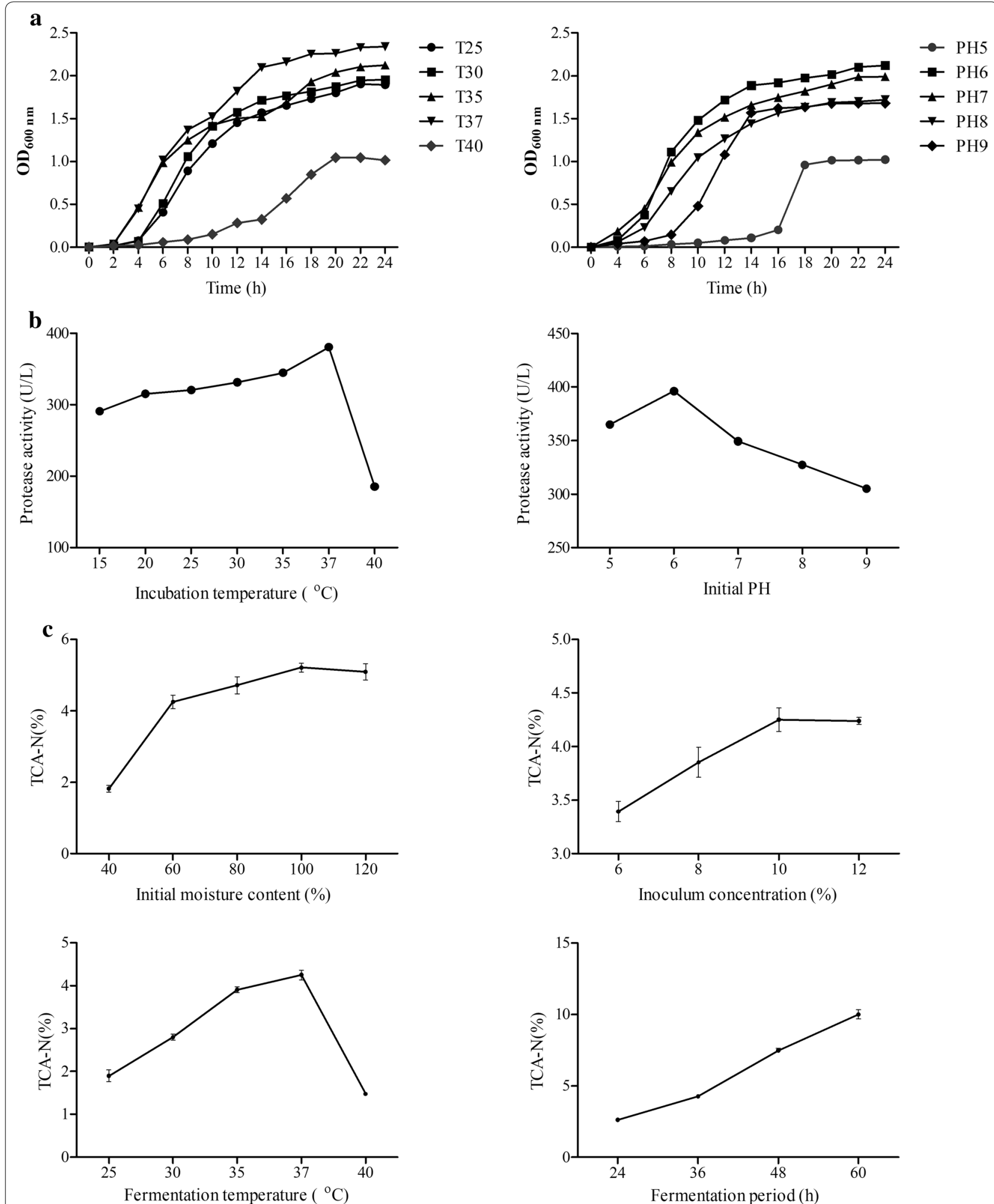

Fig. 4 Parameter optimization and characterization of Shewanella sp. MR-7. a Growth curves of Shewanella sp. MR-7 under different temperatures and $\mathrm{pH} . \mathrm{T} 25, \mathrm{~T} 30, \mathrm{~T} 35, \mathrm{~T} 37, \mathrm{~T} 40: 25^{\circ} \mathrm{C}, 30^{\circ} \mathrm{C}, 35^{\circ} \mathrm{C}, 37^{\circ} \mathrm{C}, 40^{\circ} \mathrm{C}$. $\mathbf{b}$ Effects of different temperatures and $\mathrm{pH}$ on protease production of Shewanella sp. MR-7. c Effects of initial moisture content, inoculum concentration, fermentation temperatures and fermentation period on trichloroacetic acid soluble nitrogen (TCA-N) production under solid state fermentation 
Table 2 The nutritional profile of SBM and FSBM

\begin{tabular}{|c|c|c|c|c|c|c|c|c|}
\hline Ingredients & $\begin{array}{l}\text { Crude protein } \\
(\%)\end{array}$ & Crude lipid (\%) & TCA-N (\%) & $\begin{array}{l}\text { Trypsin } \\
\text { inhibitors } \\
\left(\mathrm{mg} \mathrm{g}^{-1}\right)\end{array}$ & $\begin{array}{l}\text { Glycinin } \\
\left(\mathrm{mg} \mathrm{g}^{-1}\right)\end{array}$ & $\begin{array}{l}\beta \text {-Conglycinin } \\
\left(\mathrm{mg} \mathrm{g}^{-1}\right)\end{array}$ & $\begin{array}{l}\text { Raffinose } \\
\left(\mathrm{mg} \mathrm{g}^{-1}\right)\end{array}$ & $\begin{array}{l}\text { Stachyose } \\
\left(\mathrm{mg} \mathrm{g}^{-1}\right)\end{array}$ \\
\hline SBM & $52.97 \pm 0.05^{\mathrm{a}}$ & $2.12 \pm 0.02^{\mathrm{a}}$ & $1.41 \pm 0.01^{\mathrm{a}}$ & $2.65 \pm 0.05^{\mathrm{a}}$ & $181.91 \pm 0.21^{\mathrm{a}}$ & $127.70 \pm 0.46^{\mathrm{a}}$ & $12.66 \pm 0.13^{\mathrm{a}}$ & $31.28 \pm 0.25^{\mathrm{a}}$ \\
\hline FSBM & $54.70 \pm 0.17^{b}$ & $1.66 \pm 0.03^{b}$ & $8.24 \pm 0.04^{b}$ & $0.26 \pm 0.01^{b}$ & $41.19 \pm 0.31^{b}$ & $19.76 \pm 0.23^{b}$ & $8.96 \pm 0.08^{b}$ & $23.68 \pm 0.43^{b}$ \\
\hline
\end{tabular}

Values show mean \pm standard error, $\mathrm{n}=3$; values in the same column with different superscripted small letters mean significant difference $(P<0.05)$

SBM soybean meal, FSBM Shewanella sp. MR-7 fermented soybean meal

Table 3 Growthparameters and feed utilization of juvenile turbot fed the experimental diets

\begin{tabular}{|c|c|c|c|c|c|c|c|c|c|}
\hline Treatments & FBW $(g)$ & WGR (\%) & $\begin{array}{l}\text { SGR } \\
\left(\% \text { days }^{-1}\right)\end{array}$ & SR (\%) & $\operatorname{FER}\left(\mathrm{g} \mathrm{g}^{-1}\right)$ & $\mathrm{FI}\left(\%\right.$ days $\left.^{-1}\right)$ & $\operatorname{PER}\left(\mathrm{g} \mathrm{g}^{-1}\right)$ & $\begin{array}{l}\text { ADC of dry } \\
\text { matter (\%) }\end{array}$ & $\begin{array}{l}\text { ADC of crude } \\
\text { protein (\%) }\end{array}$ \\
\hline FM & $73.92 \pm 0.90^{\mathrm{a}}$ & $8.79 \pm 0.13^{\mathrm{a}}$ & $2.89 \pm 0.01^{\mathrm{a}}$ & $98.89 \pm 1.11$ & $1.34 \pm 0.05^{\mathrm{a}}$ & $1.55 \pm 0.06^{\mathrm{a}}$ & $2.90 \pm 0.12^{\mathrm{a}}$ & $57.41 \pm 0.40^{\mathrm{a}}$ & $93.07 \pm 0.09^{a}$ \\
\hline SBM15 & $69.78 \pm 1.64^{\mathrm{a}}$ & $8.21 \pm 0.22^{\mathrm{a}}$ & $2.81 \pm 0.03^{\mathrm{a}}$ & $96.67 \pm 0.00$ & $1.29 \pm 0.01^{\mathrm{ab}}$ & $1.58 \pm 0.01^{\mathrm{ab}}$ & $2.63 \pm 0.06^{\mathrm{ab}}$ & $55.59 \pm 0.55^{\mathrm{a}}$ & $92.31 \pm 0.40^{\mathrm{a}}$ \\
\hline SBM30 & $69.38 \pm 1.60^{\mathrm{a}}$ & $8.15 \pm 0.21^{\mathrm{ab}}$ & $2.80 \pm 0.03^{\mathrm{a}}$ & $96.67 \pm 1.92$ & $1.21 \pm 0.02^{\mathrm{abc}}$ & $1.65 \pm 0.01^{\mathrm{ab}}$ & $2.60 \pm 0.13^{\mathrm{ab}}$ & $54.87 \pm 0.38^{a}$ & $91.93 \pm 0.11^{\mathrm{a}}$ \\
\hline SBM45 & $56.96 \pm 1.68^{c}$ & $6.52 \pm 0.22^{c}$ & $2.55 \pm 0.04^{c}$ & $96.67 \pm 1.92$ & $1.18 \pm 0.01^{b c}$ & $1.63 \pm 0.04^{\mathrm{ab}}$ & $2.44 \pm 0.07^{b}$ & $48.31 \pm 0.67^{b c}$ & $89.13 \pm 0.37^{b}$ \\
\hline SBM60 & $55.47 \pm 1.28^{c}$ & $6.31 \pm 0.17^{c}$ & $2.52 \pm 0.03^{c}$ & $97.78 \pm 1.11$ & $1.23 \pm 0.06^{b c}$ & $1.57 \pm 0.08^{\mathrm{ab}}$ & $2.43 \pm 0.07^{b}$ & $45.84 \pm 0.64^{c}$ & $86.94 \pm 0.19^{c}$ \\
\hline FSBM15 & $70.00 \pm 2.06^{a}$ & $8.24 \pm 0.28^{\mathrm{a}}$ & $2.81 \pm 0.04^{\mathrm{a}}$ & $95.56 \pm 1.11$ & $1.24 \pm 0.03^{a b c}$ & $1.61 \pm 0.04^{\mathrm{ab}}$ & $2.64 \pm 0.03^{\mathrm{ab}}$ & $57.10 \pm 0.31^{\mathrm{a}}$ & $93.02 \pm 0.18^{a}$ \\
\hline FSBM30 & $73.03 \pm 1.35^{\mathrm{a}}$ & $8.65 \pm 0.17^{a}$ & $2.87 \pm 0.02^{\mathrm{a}}$ & $95.56 \pm 2.22$ & $1.30 \pm 0.02^{\mathrm{ab}}$ & $1.59 \pm 0.03^{\mathrm{ab}}$ & $2.66 \pm 0.04^{\mathrm{ab}}$ & $55.48 \pm 0.59^{a}$ & $92.96 \pm 0.20^{a}$ \\
\hline FSBM45 & $68.92 \pm 2.00^{a b}$ & $8.10 \pm 0.26^{\mathrm{ab}}$ & $2.79 \pm 0.03^{\mathrm{ab}}$ & $96.67 \pm 1.92$ & $1.27 \pm 0.02^{\mathrm{ab}}$ & $1.60 \pm 0.02^{\mathrm{ab}}$ & $2.62 \pm 0.03^{\mathrm{ab}}$ & $55.39 \pm 0.63^{\mathrm{a}}$ & $92.07 \pm 0.11^{\mathrm{a}}$ \\
\hline FSBM60 & $59.47 \pm 3.84^{b c}$ & $6.86 \pm 0.50^{b c}$ & $2.60 \pm 0.08^{b c}$ & $96.67 \pm 1.92$ & $1.12 \pm 0.03^{c}$ & $1.75 \pm 0.02^{b}$ & $2.33 \pm 0.06^{\mathrm{b}}$ & $50.75 \pm 0.43^{b}$ & $88.84 \pm 0.57^{b}$ \\
\hline
\end{tabular}

Values show mean \pm standard error, $\mathrm{n}=3$; values in the same column with different superscripted small letters mean significant difference $(P<0.05)$

$F B W$ final body weight, $W G R$ weight gain rate, SGR specific growth rate, SR survival rate, FER feed efficiency ratio, FI feed intake, $P E R$ protein efficiency ratio, $A D C$ apparent digestibility coefficients

Table 4 Activity of intestinal digestive enzyme of juvenile turbot fed the experimental diets

\begin{tabular}{llll}
\hline Treatments & $\begin{array}{l}\text { Trypsin } \\
\left(\mathbf{1 0} \mathbf{~} \mathbf{~ m g}^{-\mathbf{1}}\right)\end{array}$ & $\begin{array}{l}\text { Diastase } \\
\left(\mathbf{U} \mathbf{~ m \mathbf { g } ^ { - 1 }}\right)\end{array}$ & Lipase $\left(\mathbf{U} \mathbf{~ m g}^{\mathbf{- 1}}\right)$ \\
\hline FM & $39.67 \pm 1.71^{\mathrm{ab}}$ & $0.20 \pm 0.01^{\mathrm{a}}$ & $47.14 \pm 0.98^{\mathrm{bc}}$ \\
SBM15 & $35.24 \pm 0.65^{\mathrm{bc}}$ & $0.21 \pm 0.01^{\mathrm{a}}$ & $39.17 \pm 1.18^{\mathrm{d}}$ \\
SBM30 & $32.38 \pm 0.59^{\mathrm{cd}}$ & $0.20 \pm 0.01^{\mathrm{a}}$ & $38.45 \pm 0.52^{\mathrm{d}}$ \\
SBM45 & $30.51 \pm 0.42^{\mathrm{cd}}$ & $0.15 \pm 0.01^{\mathrm{bc}}$ & $32.91 \pm 1.05^{\mathrm{d}}$ \\
SBM60 & $26.83 \pm 2.01^{\mathrm{d}}$ & $0.13 \pm 0.01^{\mathrm{c}}$ & $23.98 \pm 0.66^{\mathrm{e}}$ \\
FSBM15 & $39.50 \pm 1.17^{\mathrm{ab}}$ & $0.22 \pm 0.01^{\mathrm{a}}$ & $57.07 \pm 1.63^{\mathrm{a}}$ \\
FSBM30 & $42.52 \pm 0.65^{\mathrm{a}}$ & $0.21 \pm 0.01^{\mathrm{a}}$ & $56.61 \pm 1.50^{\mathrm{a}}$ \\
FSBM45 & $41.16 \pm 1.45^{\mathrm{a}}$ & $0.19 \pm 0.01^{\mathrm{ab}}$ & $52.28 \pm 2.13^{\mathrm{ab}}$ \\
FSBM60 & $28.40 \pm 0.93^{\mathrm{d}}$ & $0.19 \pm 0.01^{\mathrm{ab}}$ & $40.46 \pm 2.90^{\mathrm{cd}}$ \\
\hline
\end{tabular}

Values show mean \pm standard error, $n=6$; values in the same column with different superscripted small letters mean significant difference $(P<0.05)$
However, Shewanella sp. MR-7 fermentation alleviated these SBM-induced changes.

\section{Discussion}

Gut microbiota play an important role in food digestion, nutrient absorption, metabolism and immune of host aquatic animals [23]. Previous studies have isolated various fish-derived probiotics such as Weissella hellenica DS12 from Japanese flounder [24], Lactobacillus fructivorans AS17B from sea bream [25], Lactococcus lactis WFLU12 from olive flounder [26] andconfirmed their functions in immune responses and disease control. However, few studies examined the roles of host-derived strains on digestion and nutritional physiology. In this study, a Shewanella sp. MR-7 strain was isolated from the intestinal

\section{(See figure on next page.)}

Fig. 5 The intestinal morphology, integrity, and inflammation status of turbot fed experimental diets. a Representative histomorphological images from hematoxylin and eosin-stained sections and the villi height analysis of the distal intestine of turbot. $\mathbf{b}$ Effects of experimental diets on intestinal integrity marker gene expressions of turbot. c Effects of experimental diets on intestinal inflammation marker gene expressions of turbot. The value of FM group was normalized to 1.0 and the rest groups were expressed as relative expression levels to the FM group. Values show mean \pm standard error $(n=6)$ and different letters $(a, b, c)$ on top represent statistically significant results $(P<0.05)$ based on one-way analysis of variance $(A N O V A)$ by the software SPSS 19.0. $R$ villi height/lumen diameter, arbitrary units, TNF- $a$ tumor necrosis factor- $a, I L-1 \beta$ interleukin-1 $\beta$, TGF- $\beta 1$ transforming growth factor- $\beta 1$, MUC-2 mucin 2, ZO-1 zonula occluden-1 

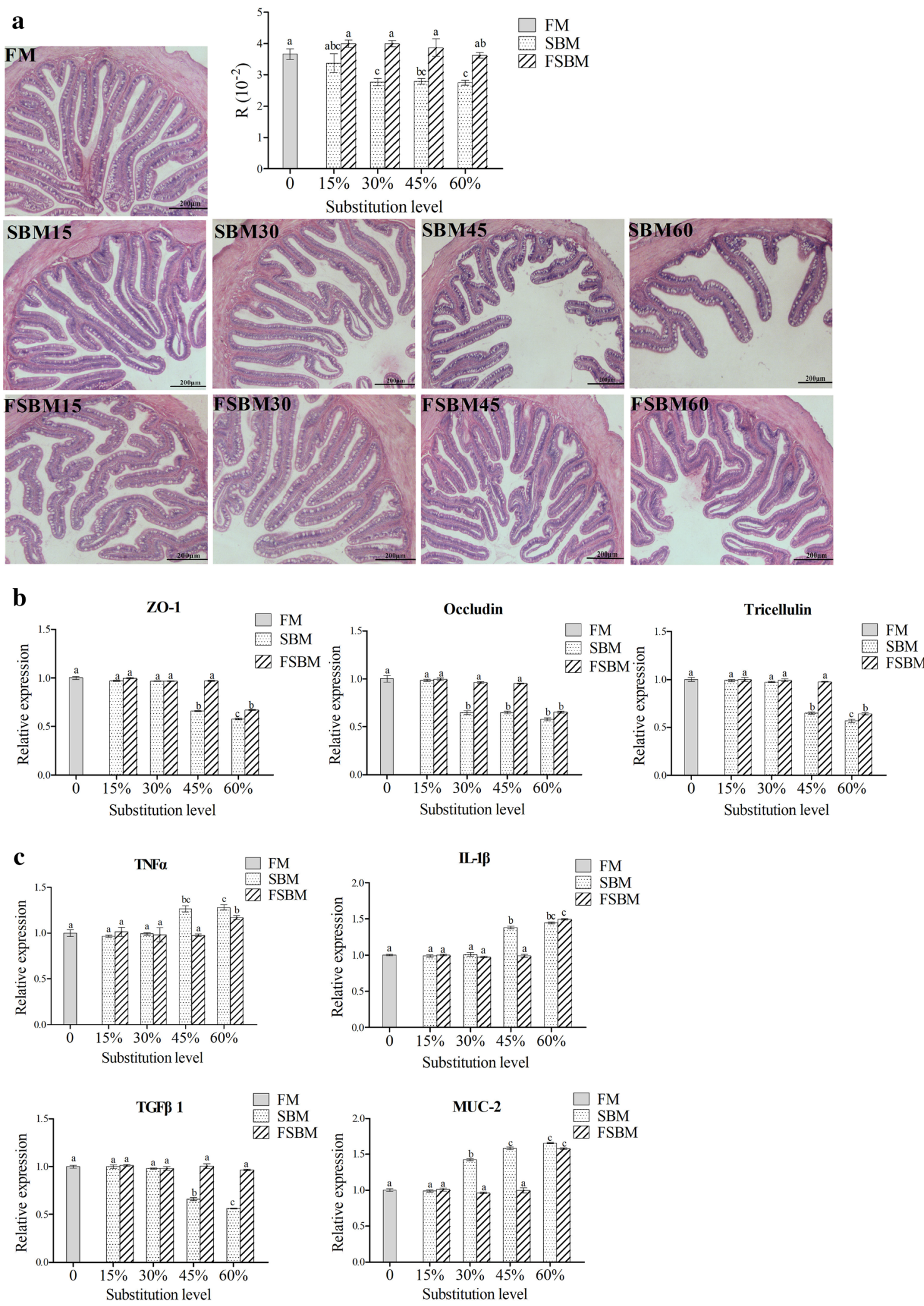

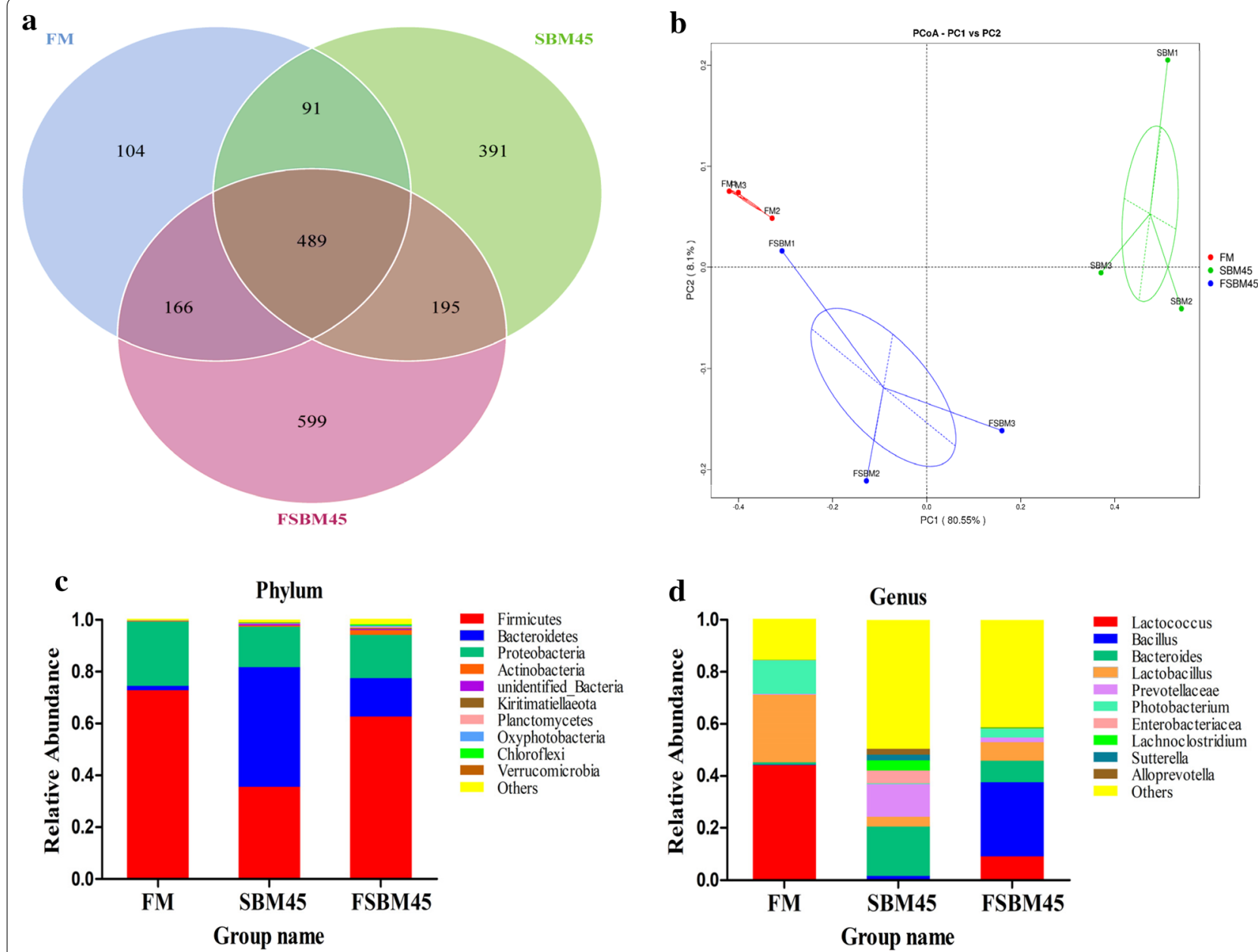

Fig. 6 Intestinal mucosal microbiome composition of turbot fed FM, SBM45 and FSBM45 diets. a Venn diagram of unique and shared OTUs. b Principal co-ordinates analysis (PCoA) for the autochthonous bacterial communities of turbot. c Taxonomy classification of reads at phylum taxonomic levels. d Taxonomy classification of reads at genus taxonomic levels. Only top 10 most abundant (based on relative abundance) bacterial phyla or genera were shown in the figures. Other phyla or genera were all assigned as 'Others'. FM1, FM2 and FM3 are three replicates of FM group; SBM1, SBM2 and SBM3 are three replicates of SBM45 group; FSBM1, FSBM2 and FSBM3 are three replicates of FSBM45 group

Table 5 Alpha diversity index of intestinal microbiota of experimental turbot

\begin{tabular}{llllll}
\hline Treatments & \multicolumn{2}{l}{ Richness estimates } & & \multicolumn{2}{l}{ Diversity estimates } \\
\cline { 2 - 3 } & Chao1 & \multicolumn{1}{c}{ ACE } & & Shannon & Simpson \\
\hline FM & $702.38 \pm 24.07^{\mathrm{a}}$ & $744.68 \pm 19.30^{\mathrm{a}}$ & & $3.39 \pm 0.30^{\mathrm{a}}$ & $0.77 \pm 0.03^{\mathrm{a}}$ \\
SBM45 & $694.79 \pm 22.30^{\mathrm{a}}$ & $690.11 \pm 19.18^{\mathrm{a}}$ & & $5.59 \pm 0.34^{\mathrm{b}}$ & $0.94 \pm 0.01^{\mathrm{b}}$ \\
FSBM45 & $851.85 \pm 28.17^{\mathrm{b}}$ & $866.88 \pm 40.26^{\mathrm{b}}$ & & $5.36 \pm 0.31^{\mathrm{b}}$ & $0.89 \pm 0.02^{\mathrm{b}}$ \\
\hline
\end{tabular}

mucosa of the turbot through directed enrichment using soybean meal (SBM) based medium. Its genetic, metabolic, and fermentation properties were characterized. The performances of its SBM fermented product was evaluated by growth, nutrition utilization, gut health and gut microbiome in turbot after a feeding trial.

Shewanella, a genus created by MacDonell and Colwell, is phylogenetically affiliated to the $\gamma$-Proteobacteria [27]. Shewanella genus was detected in turbot intestine in the present study (Additional file 1: Figure S1) as well as in previous studies [28, 29]. However, Shewanella was not among the top 10 most abundant genera (Fig. 6d and Additional file 7: Table S7), suggesting that plant protein degrading microbes such as Shewanella sp. MR-7 was not dominant in carnivorous fish like turbot, and could only be isolated through directed enrichment using plant protein based culture medium. 
Several studies have been done to explore the growth characteristics of Shewanella. The optimal growth of Shewanella marisflavi SW-117 and Shewanella aquimarina SW-120 occurred at $30-37{ }^{\circ} \mathrm{C}, \mathrm{pH}$ 7-8 [30], Shewanella waksmanii KMM 3823 at $20-22{ }^{\circ} \mathrm{C}, \mathrm{pH}$ 7.5 [31], Shewanella colwelliana ATCC 39565 at $25^{\circ} \mathrm{C}$, $\mathrm{pH}$ 7.4-7.8 [32]. In this study, Shewanella sp. MR-7 gained the optimal growth under the cultural condition of $37{ }^{\circ} \mathrm{C}$ and $\mathrm{pH}$ 6.0. These results demonstrated that the growth performance varied among different species in the genus Shewanella due to the diversity of the species.

It has been reported that gut microbiota might have beneficial effects on the digestion of fish by contributing various enzymes [20]. Most of the enzyme-producing bacteria isolated from the fish intestine so far belong to the genus Bacillus [33-35]. However, the enzyme-producing capacity of Shewanella was rarely characterized. In the present study, the strain Shewanella sp. MR-7 showed substantial production of enzymes including protease, pectinase, cellulase, hemicellulase and phytase. A considerable amount of genes in the genome of Shewanella sp. MR-7 were coded for carbohydrate and protein metabolism, suggesting its potential ability of plant protein utilizations.

Compared to SBM, fermented SBM (FSBM) by fungal and bacterial strains (predominantly Aspergillus oryzae and Lactobacillus subtilis, respectively) showed numerous benefits including degradation of anti-nutritive compounds and improvement of nutritional value of SBM [36]. In this study, trypsin inhibitor, glycinin and $\beta$-conglycinin in SBM were decreased by $90.19 \%, 77.36 \%$ and $84.52 \%$ respectively after Shewanella sp. MR-7 fermentation. We previously showed that SBM fermentation by Lactobacillus plantarum P8 degraded trypsin inhibitor, glycinin and $\beta$-conglycinin at $87 \%, 78 \%$ and $55 \%$ respectively [37]. Another study found that 50\%, 58\% and $70 \%$ of TI, glycinin subunit and $\beta$-conglycinin were removed respectively after fermentation by $B$. subtilis KCCM11438P [38]. SBM contains oligosaccharides (raffinose and stachyose) that cannot be utilized by monogastric animals [39]. In this study, the raffinose and stachyose in SBM were reduced by $29.25 \%$ and $24.25 \%$ respectively after fermentation. A previous study indicated stachyose in SBM was decreased by $83.9 \%$ after fermentation with Rhizopus oligosporus [40]. In another study, $B$. amyloliquefaciens U304 and S. cerevisiae CJ1697 drastically decreased the levels of raffinose and stachyose, while Lactobacillus spp. showed no effects against these oligosaccharides [41]. Fermentation is also able to degrade proteins and carbohydrates to low molecular weight and water-soluble compounds, which will facilitate nutrient digestibility and bioactivity [42]. Trichloroacetic acid soluble nitrogen (TCA-N) is an important index reflecting the small peptide and free amino acid content in fermented soybean meal [40]. The TCA-N was increased by $482.79 \pm 0.95 \%$ after Shewanella sp. MR-7 fermentation, which was superior to previous report showed that the TCA-N in SBM could be increased by $69 \%$ after Aspergillus oryzae fermentation [43]. Table S3 summarized the comparisons of quality parameters of FSBM by different strains. As shown above, the fermented products vary in levels of nutritional components because of the differential metabolic activities of the microbial strain used. Shewanella sp. MR-7 fermentation significantly improved the quality of SBM and was comparable and even superior to a lot of strains currently used for SBM fermentations.

Along with our previous studies [37], we showed that SBM could replace up to $30 \%$ of fishmeal without adverse effects in turbot diet. In the present study, FSBM by Shewanella sp. MR-7 improved the fishmeal replacement level to $45 \%$ without influencing the growth performance of the turbot. Suppression of feed intake (FI), poor nutrient digestibility and presence of ANFs have been considered the major limitations of plant protein usages in aquaculture [44, 45]. In the present study, dietary FSBM did not suppress the FI and enhanced the apparent digestibility coefficients (ADC), which were lower at the same inclusion levels of the SBM. As discussed above, Shewanella sp. MR-7 also showed superior abilities of degrading multiple ANFs in SBM. The significantly improved quality of FSBM and enhanced ADC values of FSBM diets could be partially account for the better growth performance of turbot in FSBM groups.

The activity of intestinal digestive enzymes is an important indicator reflecting the ability of feed digestion [46]. In parallel with the aforementioned findings in ADC values, dietary FSBM also remarkably ameliorated SBMinduced decrease of the intestinal digestive enzymes (trypsin, lipase and diastase) activities. It was known that ANFs in SBM could inhibit digestive enzyme activities thereby affecting the efficiency of the digestive process [47]. Previous studies also suggested that gut microbiota contributed host digestions by producing various enzymes [20]. In the present study, the better profile of digestive enzymes in FSBM groups might be due to degradation of ANFs and modulation of gut microbiota by dietary FSBM diets.

The present study, as well as previous reports, demonstrated that high inclusion of SBM caused enteritis, which was a major contributor of the inferior performance of the diets [18]. This was further confirmed by the reduced expression levels of intestinal tight junction proteins including $\mathrm{ZO}-1$, tricellulin, and occludin. Similar results were observed in Atlantic salmon 
treated with SBM diets [48-50]. Furthermore, the expression levels of pro-inflammatory (IL- $1 \beta$ and TNF$\alpha)$ and anti-inflammatory (TGF- $\beta 1$ ) cytokines were significantly increased or decreased respectively in SBM groups with dietary fishmeal replacement $\geq 45 \%$. Mechanistically, IL- $1 \beta$ and TNF- $\alpha$ could influence the intestinal barrier through reducing the levels of ZO-1 and occludin via MLCK signaling pathway [51, 52]. Mediated through NF-kB and P13K/Akt signaling pathways, these pro-inflammatory responses could also stimulate the level of MUC-2 [53-55], which was also a biomarker for intestinal inflammation [22] and up regulated in SBM groups.Actually, the antigenic components of glycinin and $\beta$-conglycinin in SBM may be primarily accounted for the gut pathological alterations and detrimental inflammatory response [56, 57]. In contrast, judged from histology, the expression of above pro-inflammatory and tight junction factors, the intestines of FSBM groups remained healthy except some inflammatory response of FSBM60. In the present study, most of the glycinin (77.36\%) and $\beta$-conglycinin $(84.52 \%)$ in SBM were degraded by Shewanella sp. MR-7 fermentation, which could be responsible for the improved gut health of turbot fed FSBM diets. In addition, recent study indicated that soya-saponins induced enteritis and compromised the intestinal barrier functions in turbot [58]. The possibly degrading soya-saponins in FSBM may partially be accounted for the improved gut health that study on the quantitative analyses of soya-saponins contents in SBM and FSBM could be performed in the future.

Numerous studies have suggested that a healthy microbiota is critical for gut function and health [5961]. Microbial dysbiosis is involved in various diseases including chronic enteritis in humans and mammals $[62,63]$. The intestine mucosal microbiota of turbot was dominated by Firmicutes and Proteobacteria, which was in line with previous study [64]. Dietary inclusion of SBM increased the bacteria diversity, changed the relative abundance of the dominant taxon and genus, and resulted in a significantly different microbial community from that of control group, which was FM fed. Similar results were obtained in previous studies on turbot [65] and other carnivorous fish [66, 67], suggesting that dietary plant protein source may increase diversity and alter the structure of the intestinal autochthonous bacteria communities. Specifically, the microbiota of SBM45 group showed significantly increased abundances of Prevotellaceae and Enterobacteriaceae, some of which were considered as potentially colitogenic bacteria in humans and mammals [68, 69]. However, the relative abundances of the recognized probiotics, Lactococcus and Lactobacillus [70], were significantly decreased in
SBM45 group compared to control. Few studies have been done to explore the effects of dietary fermented soybean meal on gut microbiome of carnivorous fish. Our data demonstrated that Shewanella sp. MR-7 fermentation could significantly alleviate the SBM-induced gut microbiota dysbiosis by enhancing potentially probiotic and inhibiting pathogenic bacteria.

\section{Conclusions}

In the present study, the isolated intestinal autochthonous microbe, Shewanella sp. MR-7, could greatly improve the protein availability and degrade multiple anti-nutritional factors of SBM by fermentation. Shewanella sp. MR-7 fermentation significantly counteracted the SBM-induced adverse effects by increasing digestive enzymes activities, suppressing inflammatory responses, and alleviating microbiota dysbiosis in the intestine of turbot. This study confirmed the role of specific intestinal autochthonous microbe in the expansion of host metabolic capacity and provide clues for discovery and development of new fermentation strains.

\section{Methods \\ Isolation and identification of proteolytic bacteria from turbot}

Healthy turbots $(\sim 500 \mathrm{~g}$ in weight) were obtained from Yihaifeng fish farm Inc. Intestinal mucosa samples were collected and handled as previously described with modifications [66, 71]. Specifically, intestines were aseptically dissected and intestinal mucosa were scraped and collected in sterile tubes. All samples were serially diluted with sterile artificial seawater and inoculated into skimmed milk powder medium at $22{ }^{\circ} \mathrm{C}$ to reach the $\mathrm{OD}$ value $>0.5$, thus enriching the proteolytic bacteria [72]. Subsequently, $100 \mu \mathrm{L}$ of the cultured solution was inoculated into soybean meal (SBM) liquid medium (SBM, $5.0 \mathrm{~g} \mathrm{~L}^{-1}$; sea salt, $36.0 \mathrm{~g} \mathrm{~L}^{-1}$ ) at $22^{\circ} \mathrm{C}$ to reach $\mathrm{OD}$ value $>0.5$. The cultured solutions were serially diluted every tenfold and inoculated onto casein agar (1\% casein in $5 \mathrm{M} \mathrm{NaOH}$ and sea salt medium at 1:1 with $1.5 \%$ agar) to screen out the strains with superior protease-producing ability [73]. The plates were incubated at $22{ }^{\circ} \mathrm{C}$ and detected if clear zone would be produced. Colonies producing a halo with diameter exceeding $4 \mathrm{~cm}$ were selected and purified by dilution streaking method. All the purified colonies were further identified based on biochemical tests and 16S rRNA gene sequencing. Moreover, the selected clones were inoculated into the SBM liquid medium for $48 \mathrm{~h}$ at $22{ }^{\circ} \mathrm{C}$. The supernatant of un-inoculated and inoculated SBM liquid medium were collected by centrifuging at $10,000 \mathrm{rpm}$ for $1 \mathrm{~min}$. The soluble protein content in supernatant was measured using Folin-Phenol method [74]. 
Table 6 Formulas and proximate composition of the experimental diets (\% dry matter)

\begin{tabular}{|c|c|c|c|c|c|c|c|c|c|}
\hline \multirow[t]{2}{*}{ Ingredients } & \multicolumn{9}{|c|}{ Treatments } \\
\hline & FM & SBM15 & SBM30 & SBM45 & SBM60 & FSBM15 & FSBM30 & FSBM45 & FSBM60 \\
\hline Fish meal ${ }^{\mathrm{a}}$ & 60.00 & 51.00 & 42.00 & 33.00 & 24.00 & 51.00 & 42.00 & 33.00 & 24.00 \\
\hline Soybean meal ${ }^{\mathrm{a}}$ & - & 12.34 & 24.69 & 37.03 & 49.37 & - & - & - & - \\
\hline Fermented soybean meal ${ }^{b}$ & - & - & - & - & - & 11.95 & 23.90 & 35.86 & 47.81 \\
\hline Wheat meal ${ }^{\mathrm{a}}$ & 24.94 & 18.00 & 13.46 & 8.30 & 3.48 & 18.49 & 14.06 & 9.77 & 4.81 \\
\hline Wheat gluten meal ${ }^{a}$ & 2.46 & 3.73 & 4.51 & 5.30 & 6.27 & 3.63 & 4.39 & 5.00 & 6.21 \\
\hline Fish oil & 4.60 & 4.80 & 5.10 & 5.90 & 6.40 & 4.80 & 5.40 & 5.90 & 6.70 \\
\hline Amino acid & 0.00 & 0.12 & 0.25 & 0.47 & 0.48 & 0.12 & 0.25 & 0.47 & 0.47 \\
\hline Taurine & 0.00 & 1.00 & 1.00 & 1.00 & 1.00 & 1.00 & 1.00 & 1.00 & 1.00 \\
\hline Vitamin premix & 2.00 & 2.00 & 2.00 & 2.00 & 2.00 & 2.00 & 2.00 & 2.00 & 2.00 \\
\hline Mineral premix & 1.00 & 1.00 & 1.00 & 1.00 & 1.00 & 1.00 & 1.00 & 1.00 & 1.00 \\
\hline Attractant ${ }^{\mathrm{e}}$ & 1.00 & 1.00 & 1.00 & 1.00 & 1.00 & 1.00 & 1.00 & 1.00 & 1.00 \\
\hline Cholesterol & 0.00 & 1.00 & 1.00 & 1.00 & 1.00 & 1.00 & 1.00 & 1.00 & 1.00 \\
\hline Others $^{f}$ & 4.00 & 4.00 & 4.00 & 4.00 & 4.00 & 4.00 & 4.00 & 4.00 & 4.00 \\
\hline \multicolumn{10}{|c|}{ Analytical composition (dry matter, \%) } \\
\hline Energy $\left(\mathrm{kJ} \mathrm{g}^{-1}\right)$ & 20.19 & 20.24 & 20.27 & 20.38 & 20.49 & 20.15 & 20.15 & 20.11 & 20.20 \\
\hline Crude protein & 50.00 & 50.00 & 50.00 & 50.00 & 50.00 & 50.00 & 50.00 & 50.00 & 50.17 \\
\hline Crude lipid & 12.19 & 12.79 & 12.49 & 12.69 & 12.60 & 12.73 & 12.67 & 12.51 & 12.65 \\
\hline
\end{tabular}

FM diet fish meal, SBM15 replacement of $15 \%$ fish meal protein by soybean meal protein, SBM30 replacement of $30 \%$ fish meal protein by soybean meal protein, SBM45 replacement of $45 \%$ fish meal protein by soybean meal protein, SBM60 replacement of $60 \%$ fish meal protein by soybean meal protein, FSBM 15 replacement of $15 \%$ fish meal protein by fermented soybean meal protein, FSBM 30 replacement of $30 \%$ fish meal protein by fermented soybean meal protein, FSBM 45 replacement of $45 \%$ fish meal protein by fermented soybean meal protein, FSBM 60 replacement of $60 \%$ fish meal protein by fermented soybean meal protein

a Supplied by Great seven Bio-Tech (Qingdao, China); fish meal, crude protein, 73.77\%, crude lipid, 7.58\%; soybean meal, crude protein, 52.97\%, crude lipid, 2.12\%; wheat meal, crude protein, $17.82 \%$, crude lipid, 2.24\%; wheat gluten meal, crude protein, $83.31 \%$, crude lipid, $1.75 \%$

b Fermented soybean meal got from soybean meal fermented with Shewanella sp. MR-7, crude protein, 54.70\%, crude lipid, 1.66\%

c Vitamin premix ( $\mathrm{mg} \mathrm{kg}^{-1}$ diet): retinal palmitate, 32; cholecalciferol, 5; DL-a-tocopherol acetate, 240; menadione, 10; thiamin-HCl, 25; riboflavin, 45; pyridoxine-HCl, 20; cyanocobalamin, 10; D-calcium pantothenate, 60; amine nicotinic acid, 200; folic acid, 20; biotin, 60; mesoinositol, 800; ascorbyl polyphosphate (contained 35\% ascorbic acid), 2000; microcrystalline cellulose, 16,473

d Mineral premix (mg kg ${ }^{-1}$ diet): $\mathrm{MgSO}_{4} \cdot 7 \mathrm{H}_{2} \mathrm{O}, 1200 ; \mathrm{CuSO}_{4} \cdot 5 \mathrm{H}_{2} \mathrm{O}, 10 ; \mathrm{FeSO}_{4} \cdot \mathrm{H}_{2} \mathrm{O}, 80 ; \mathrm{ZnSO}_{4} \cdot \mathrm{H}_{2} \mathrm{O}, 50 ; \mathrm{MnSO}_{4} \cdot \mathrm{H}_{2} \mathrm{O}, 45 ; \mathrm{CoCl}_{2} \cdot 6 \mathrm{H}_{2} \mathrm{O}(1 \%), 50 ; \mathrm{Na}_{2} \mathrm{SeO}_{3}(1 \%), 20 ; \mathrm{calcium}^{2}$ iodine, 60; zeolite, 8485

e Attractant:betaine:dimethyl-propiothetin:glycine:alanine:5-phosphateinosine = 4:2:2:1:1

f Others ( $10 \mathrm{~g} \mathrm{~kg}^{-1}$ diet): soy lectithin, 2.00; monocalcium phosphate, 1.00; choline chloride, 0.30; Yttrium oxide, 0.10 ; calcium propionic acid, 0.05 ; ethoxyquin, 0.05 ; sodium alginate, 0.50

\section{Genomic sequencing and bioinformatic analyses}

For genomic sequencing and bioinformatic analyses, the bacterial DNA was extracted and purified using the Wizard $^{\circledR}$ Genomic DNA Purification Kit (Promega). The quantity of the DNA was measured using a TBS-380 fluorometer (Turner BioSystems Inc., Sunnyvale, CA). High quality DNA (OD260/280=1.8-2.0, > $1 \mu \mathrm{g}$ ) was used in sequencing library construction using the NEXTflex $^{\mathrm{TM}}$ Rapid DNA-Seq Kit. The library was PCR amplified and used for paired-end Illumina sequencing $(2 \times 150 \mathrm{bp})$ on an Illumina HiSeq $\mathrm{X}$ Ten machine. Low quality data in the raw reads was removed to form clean data by a statistic of quality information for quality trimming, and the clean reads were assembled by SOAPdenovo v2.04. The inner gaps that emerged in the scaffold were filled using the Gap Closer version 1.12. The scaffolds were then uploaded to the CGView Server to plot the graphical circular genome map [75]. The coding sequences
(CDS) were predicted using Glimmer version 3.02 and annotated from the Clusters of Orthologus Groups (COG), Kyoto Encyclopedia of Genes and Genomes (KEGG), and Gene Ontology (GO) databases [76] using sequence alignment tools such as BLAST, Diamond and HMMER. tRNA and rRNA sequences were predicted by tRNA-scan-SE (v1.2.1) [77] and RNAmmer (v1.2) [78], respectively.

\section{Parameter optimization of Shewanella sp. MR-7}

The isolated strain of Shewanella sp. MR-7 was cultured in 2216E medium (Qingdao Haibo) and shaken at $220 \mathrm{rpm}$ at $25,30,35,37$ and $40{ }^{\circ} \mathrm{C}$ to determine the effects of temperature on the growth of Shewanella sp. MR-7. The Shewanella sp. MR-7 was also cultured in 2216E medium at $\mathrm{pH} 5.0,6.0,7.0,8.0,9.0$ to examine the effect of $\mathrm{pH}$ on its growth. The $\mathrm{OD}_{600}$ of the culture was taken periodically. The influences of temperature and $\mathrm{pH}$ 
Table 7 Sequences of primers used in this study for qRT-PCR

\begin{tabular}{|c|c|c|c|}
\hline Target gene & Forward primer $\left(5^{\prime}-3^{\prime}\right)$ & Reverse primer $\left(5^{\prime}-3^{\prime}\right)$ & $\begin{array}{l}\text { GenBank } \\
\text { accession } \\
\text { number }\end{array}$ \\
\hline TNFa & CCCTTATCATTATGGCCCTT & TCCGAGTACCGCCATATCCT & FJ654645.1 \\
\hline $\mid L-1 \beta$ & TACCTGTCGTGCCAACAGGAA & TGATGTACCAGTTGGGGAA & AJ295836.2 \\
\hline TGF $\beta 1$ & CTGCAGGACTGGCTCAAAGG & CATGGTCAGGATGTATGGTGGT & KU238187 \\
\hline MUC-2 & GTTGGTGCAGCCGCATAG & CACTGGACGCTGGGAATG & KU238186 \\
\hline ZO-1 transcript variant 1 & AGAGAACCTGTCACTGATAGATGC & CTGTCGGAATTGTTGCCTGATG & KU238184 \\
\hline Occludin & ACTGGCATTCTTCATCGC & GGTACAGATTCTGGCACATC & KU238182 \\
\hline Tricellulin & GCCTACATCCACAAAGACAACG & TCATTCCCAGCACTAATACAATCAC & KU238183 \\
\hline$\beta$-Actin & GCTGTCTTCCCTTCTATCGTCG & TCCATGTCATCCCAGTTGGTC & AY008305.1 \\
\hline
\end{tabular}

TNF- $\alpha$ tumor necrosis factor- $\alpha$, IL-1 $\beta$ interleukin-1 $\beta$, TGF- $\beta 1$ transforming growth factor- $\beta 1$, MUC-2 mucin 2, ZO-1 zonula occluden-1

on the production of protease by Shewanella sp. MR-7 were determined by enzyme-linked immunosorbent assay (ELISA) [79] using protease ELISA kits (HengYuan Biological Technology Co., Ltd, Shanghai, China).

To optimize the solid state fermentation parameters of Shewanella sp. MR-7 for soybean meal, Shewanella sp. MR-7 grown in 2216E liquid medium was inoculated with soybean meal with series levels of initial inoculum (6\%, 8\%, 10\%, 12\%), moisture (40, 60, 80, 100 and 120\%), temperature $\left(25,30,35,37\right.$ and $\left.40{ }^{\circ} \mathrm{C}\right)$, and fermentation period ( $24 \mathrm{~h}, 36 \mathrm{~h}, 48 \mathrm{~h}$ and $60 \mathrm{~h}$ ). The corresponding optimal parameters were determined respectively by quantification of trichloroacetic acid soluble nitrogen (TCA-N) production under solid state fermentation. All experiments were carried out in triplicates. The TCA-N production was determined by a modified method according to the previous study [43]. Briefly, approximately $3.0000 \mathrm{~g}$ of sample was placed in a $250 \mathrm{~mL}$ conical flask, $100 \mathrm{~mL}$ of $15 \%$ trichloroacetic acid solution was added and the mixture was shaken for $30 \mathrm{~min}$ at room temperature. After standing for $5 \mathrm{~min}$, the supernatant was collected and centrifuged at $4800 \mathrm{~g}$ for $10 \mathrm{~min}$. The nitrogen content in final supernatant was determined by Kjeldahl method [80].

\section{Soybean meal fermentation and experimental diet preparation}

The soybean meal was fermentedusing parameters optimized above with minor modifications. Briefly, SBM soaked with $100 \%$ distilled water (contained $2.6 \%$ sea salt, 3.3\%o $\left(\mathrm{NH}_{4}\right)_{2} \mathrm{SO}_{4}, 1.3 \%$ glucose) was autoclaved at $105{ }^{\circ} \mathrm{C}$ for $20 \mathrm{~min}$ in a steam tank (model HX14G1, Shanghai, China) and cooled to room temperature. Thereafter, the SBM were inoculated with $10 \%$ of Shewanella sp. MR-7 $\left(\sim 10^{8}\right.$ colony forming units (cfu) $\mathrm{mL}^{-1}$ ) and fermented in an incubator at $37{ }^{\circ} \mathrm{C}$ for $48 \mathrm{~h}$. The resulting FSBM was dried in an oven at $45^{\circ} \mathrm{C}$ until its moisture content was below $10 \%$. The FSBM samples were collected for nutritional profiling.

The composition of experimental diets was shown in Table 6. Nine isonitrogenous (approximately 50\% crude protein) and isoenergetic (approximately $20.0 \mathrm{~kJ} \mathrm{~g}^{-1}$ diet of gross energy) diets were formulated with $0 \%$ (FM), $15 \%$ (SBM15/FSBM15), 30\% (SBM30/FSBM30), 45\% (SBM45/ FSBM45) and 60\% (SBM60/FSBM60) of protein from FM replaced by SBM or FSBM respectively. Lysine and methionine were supplemented in all diets to the level of FM diet to meet the essential amino acid requirements of juvenile turbot. $\mathrm{Y}_{2} \mathrm{O}_{3}(0.1 \%)$ was supplemented as the indicator for the apparent digestibility determination. Experimental diets were made following the previous procedure [21] using a pellet-making machine (F-26 (II), South China University of Technology).

\section{Feeding trial and sampling}

Juvenile turbots were purchased from a fish rearing farm (Yantai, China). Experiments were done in a flowing water system of Yi Haifeng Aquatic Product CO. Ltd (Qingdao, China). Before the start of the feeding trial, all the fish were acclimated to the culture system for 2 weeks by feeding the commercial diets. After being fasted for $24 \mathrm{~h}$, juvenile turbots with initial weight at $7.57 \pm 0.03 \mathrm{~g}$ were randomly assigned to 27 experimental fiber glass tanks (30 fish/tank) with each experimental diet assigned to three tanks randomly. Fish were manually fed twice daily at 7:00 and 19:00 till apparent satiation for 79 days.

At the end of 79-day feeding trial, all experimental fish were anesthetized with eugenol (1: 10,000, Shanghai Reagent Co., Shanghai, China). The total number and body weight of the fish in each tank were measured. Five fish from each tank were randomly sampled and stored at $-20{ }^{\circ} \mathrm{C}$ for whole body composition analysis. At about $8 \mathrm{~h}$ after feeding, only fish with digesta throughout the intestinal tract were sampled for further analysis 
to ensure intestinal exposure to the diets. The intestine was removed, cleared of any contents, and rinsed several times with ice-cold PBS. The whole intestines and distal intestines of four fish from each tank were sampled separately and stored at $-80{ }^{\circ} \mathrm{C}$ for digestive enzymes and quantitative real-time polymerase chain reaction (qRTPCR) analyses. The entire intestines of another three fish from each tank were immersed in Bouin's fixative solution and then transferred into $70 \%$ ethanol after $24 \mathrm{~h}$ for histological evaluation. Moreover, fecal samples were collected from each tank using an automatic fecal collector by siphoning $5 \mathrm{~h}$ after feeding from the fifth week of feeding trial. Collected fecal samples were stored at $-20{ }^{\circ} \mathrm{C}$ prior to digestibility determination.

For intestinal microbiome analyses, another six fish from each tank were sacrificed and sampled as previously described with modifications [71]. Briefly, the exterior of fish was decontaminated with $70 \%$ ethanol, after which the abdomen was dissected withsterile anatomic tools near an alcohol burner and the whole intestine was aseptically removed and opened longitudinally. The contents were removed by mechanical force with forceps. After rinsing the evacuated gut several times with sterile PBS, the intestinal mucosa from the whole intestine was scraped with a sterile scalpel and collected in sterile $1.5 \mathrm{~mL}$ tubes. The mucosae of six fish from each tank were pooled as one sample and three samples per dietary group were obtained. All the samples were immediately frozen in liquid nitrogen, and thereafter stored at $-80^{\circ} \mathrm{C}$.

\section{Biochemical analyses}

The glycinin and $\beta$-conglycinin of SBM and FSBM were measured by competitive enzyme-linked immunosorbent assay (ELISA) as previously described [81]. Trypsin inhibitors activity was measured using benzoyl-DL-arginine- $p$-nitroanilide (BAPA) method [82]. Raffinose and stachyose were determined using high-performance liquid chromatography (HPLC) as previously described [83]. To measure the apparent digestibility of the diets, the $\mathrm{Y}_{2} \mathrm{O}_{3}$ content in the fecal samples and diets were determined by Inductively Coupled Plasma-atomic Emission SMectrophotometer (ICP-OES, VISTA-MPX) after an acid digestion with perchloric acid [84]. Moisture, crude protein, crude lipid and energy of the diets, ingredients and fish samples were determined using standard method [80]. For digestive enzyme assays, intestine samples were homogenized in ice-cold normal saline and centrifuged at $4000 \mathrm{~g}$ for $20 \mathrm{~min}$ at $4{ }^{\circ} \mathrm{C}$ to collect the supernatant. The trypsin, amylase and lipase activities were determined as described before [85] using enzymatic assay kits (Jiancheng Bioengineering Institute, China).

\section{Intestinal histological analyses}

After fixation in Bouin's solution, the distal intestine tissue samples were transferred into $70 \%$ ethyl alcohol. Segments of the fixed tissues were dehydrated in a series dilution of ethanol solutions, equilibrated in xylene and embedded in paraffin. Sections $(\sim 7 \mu \mathrm{m})$ were mounted onto albumin coated slides and stained with hematoxylin and eosin (H\&E). The slides were observed under an imaging microscope (Olympus, DP72, Nikon, Japan). The ratio (R) between the villi height $(\mathrm{VH})$ and the lumen diameter (LD) of the gut was measured $[R=V H / L D$, arbitrary units $(A U)]$. VH of $H \& E$ stained hindgut section was determined by measuring about 8-10 well-oriented villus in each sample. A high $R$ value indicates high villi height.

\section{Quantitative real-time polymerase chain reaction (qRT-PCR)}

The expression profiles of mucin-2 (MUC-2) gene, inflammatory marker genes of interleukin-1 beta (IL$1 \beta)$, tumour necrosis factor alpha (TNF- $\alpha$ ), transforming growth factor beta1 (TGF- $\beta 1$ ) and tight junction-related genes of zonula occluden-1 (ZO-1) transcript variant 1 , occludin and tricellulin were determined using quantitative real-time PCR (qRT-PCR). Total RNA was extracted from distal intestine tissue samples (12 samples/treatment) using TRIzol Reagent (Invitrogen, Carlsbad, CA). High quality RNA with a 260/280-nm absorbance ratio of 1.8-2.0 was reversely transcribed to cDNA by the Primer ScriptTM RT reagent Kit (Takara, China). The qRT-PCR reactions were carried out in $25 \mu \mathrm{L}$ reaction volume according to previous report [18]. The thermal profile was $95^{\circ} \mathrm{C}$ for $20 \mathrm{~s}$, followed by 39 cycles of $95^{\circ} \mathrm{C}$ for $5 \mathrm{~s}, 57-58^{\circ} \mathrm{C}$ for $30 \mathrm{~s}$, and $72{ }^{\circ} \mathrm{C}$ for $30 \mathrm{~s}$. Three replicate extractions were performed for each sample. To calculate the expression levels of target genes, values were normalized to $\beta$-actin (the house-keeping gene), as no expression changes of $\beta$-actin were observed in distal intestines among different treatments. The gene expression levels were calculated by $2^{-\Delta \Delta C T}$ method [86]. The data were reported as fold increase of the control (FM). All primer sequences of target genes were listed in Table 7.

\section{Intestinal microbiome profiling}

The bacterial DNA from intestinal mucosa samples was extracted using the QIAamp DNA Stool Mini Kit (Qiagen, Hilden, Germany). The quantity and purity of the DNA were assessed using a Nano Drop ${ }^{\circledR} 2000$ spectrophotometer (Thermo Fisher Scientific, USA). The integrity of DNA was monitored on $1 \%$ agarose gels. Then, DNA was diluted to $1 \mathrm{ng} \mu \mathrm{L}^{-1}$ using sterile water and $16 \mathrm{~S}$ rRNA genes of distinct regions (16SV4) were amplified 
using specific primer pair 515F (5'-GTGCCAGCMGCC GCGG-3') and 806R (5'-GGACTACHVGGGTWT CTAAT-3') with the barcode. All PCR reactions were carried out with Phusion ${ }^{\circledR}$ High-Fidelity PCR Master Mix (New England Biolabs). Thermal cycling consisted of initial denaturation at $98^{\circ} \mathrm{C}$ for $1 \mathrm{~min}$, followed by 30 cycles of denaturation at $98{ }^{\circ} \mathrm{C}$ for $10 \mathrm{~s}$, annealing at $50{ }^{\circ} \mathrm{C}$ for $30 \mathrm{~s}$, and elongation at $72{ }^{\circ} \mathrm{C}$ for $30 \mathrm{~s}$. PCR products from all samples were mixed in equidensity ratios and purified using the GeneJET ${ }^{\mathrm{TM}}$ Gel Extraction Kit (Thermo Scientific). Sequencing libraries were generated using Ion Plus Fragment Library Kit 48 rxns (Thermo Scientific) according to manufacturer's recommendations. The library quality was evaluated on the Qubit@ 2.0 Fluorometer (Thermo Scientific). Finally, the library was sequenced on an Ion $\mathrm{S}^{\mathrm{TM}}$ XL platform and $400 \mathrm{bp}$ single-end reads were generated.

Single-end reads was assigned to samples based on their unique barcode and truncated by cutting off the barcode and primer sequence. Quality filtering on the raw reads were performed under specific filtering conditions to obtain the high-quality clean reads according to the Cutadapt (v1.9.1) [87] quality-controlled process. The reads were compared with the reference database (Silva database) [88] using UCHIME algorithm [89] to detect chimera sequences, and then the chimera sequences were removed [90]. Then the Clean Reads were finally obtained. Sequences analysis was performed by Uparse software (Uparse v7.0.1001) [91]. Sequences with $\geq 97 \%$ similarity were assigned to the same operational taxonomic units (OTUs). Representative sequence for each OTU was screened for further annotation. For each representative sequence, the Silva Database (Version 132) [88] was used based on Mothur algorithm to annotate taxonomic information.

In order to study the phylogenetic relationship of different OTUs, and the difference of the dominant species in different samples (groups), multiple sequence alignments were conducted using the MUSCLE software (v3.8.31) [92]. OTUs abundance information was normalized using a standard of sequence number corresponding to the sample with the least sequences. Subsequent analysis of alpha diversity and beta diversity were all performed basing on this output normalized data. Alpha diversity was applied in analyzing complexity of species diversity for samples through 4 indices, including Chao1, ACE, Shannon and Simpson. All the indices in our samples were calculated with QIIME (v1.7.0) and displayed with $\mathrm{R}$ software (v2.15.3). Chao1 and ACE were selected to identify community richness and Shannon and Simpson were selected to identify community diversity. Beta diversity analysis of Principal Coordinate Analysis (PCoA) was used to evaluate differences of samples in species complexity. PCoA analysis was displayed by WGCNA package, stat packages and ggplot2 package in $\mathrm{R}$ software (v2.15.3). Tukey's test and wilcox's test were used to test statistical difference of alpha diversity and beta diversity between treatments.

\section{Calculations and statistical methods}

The following variables were calculated:

$$
\begin{aligned}
\text { Survival rate }(\mathrm{SR}, \%)= & (\text { final fish number } \\
& / \text { initial fish number }) \times 100 \% .
\end{aligned}
$$

$$
\begin{aligned}
\text { Weight gain rate }(\text { WGR, \% })= & (\text { final body weight } \\
& - \text { initial body weight }) \\
& / \text { initial body weight } \times 100 \% .
\end{aligned}
$$

Specific growth rate $(\mathrm{SGR}, \%)=\mathrm{Ln}$ (final body weight

$$
\begin{aligned}
& \text { /initial body weight) } \\
& \text { /days } \times 100 \% \text {. }
\end{aligned}
$$

Feed intake $(\mathrm{FI}, \%)=$ dry total feed intake

$$
\begin{aligned}
& /[(\text { final total body weight } \\
& + \text { initial total body weight }) / 2] \\
& \text { /days } \times 100 \% \text {. }
\end{aligned}
$$

$$
\begin{array}{r}
\text { Feed efficiency ratio }(\text { FER })=\text { wet weight gain }(\mathrm{g}) \\
\\
\text { /dry feed intake }(\mathrm{g}) .
\end{array}
$$

$$
\text { Protein efficiency ratio(PER) }=\text { wet weight gain }(\mathrm{g})
$$
/protein ingested (g).

$$
\begin{aligned}
& \text { Apparent digestibility coefficients (ADC, \%) } \\
& =\left(1-\mathrm{Y}_{2} \mathrm{O}_{3} \text { in the diet } / \mathrm{Y}_{2} \mathrm{O}_{3}\right. \text { in feces } \\
& \quad \times \text { nutrient in feces/nutrient in diets }) \times 100 \% .
\end{aligned}
$$

All statistical evaluations were analyzed using oneway analysis of variance (ANOVA) by the software SPSS 19.0. Prior to the statistical tests, data were examined for homogeneity of variances. Differences between the means were tested by Tukey's multiple comparison method. Differences were regarded as significant when $P<0.05$. Data were expressed as mean \pm standard error. 


\section{Supplementary information}

Supplementary information accompanies this paper at https://doi. org/10.1186/s12934-019-1265-z.

Additional file 1: Figure S1. Bacterial genera in the intestine of turbot used for the microbe isolation in this study.

Additional file 2: Table S2. COG function annotation of Shewanella sp. MR-7.

Additional file 3: Table S3. KEGG pathway of Shewanella sp. MR-7.

Additional file 4: Table S4. Genes involved in fatty acid metabolism in the genome of Shewanella sp. MR-7.

Additional file 5: Table S5. The comparisons of quality parameters of FSBM by Shewanella sp. MR-7 and other representative strains. Figure S2. Rarefaction curves of observed species number for all the intestinal microbiome samples.

Additional file 6: Table S6. The relative abundance of intestinal bacterial OTUs at phylum taxonomic levels.

Additional file 7: Table S7. The relative abundance of intestinal bacterial OTUs at genus taxonomic levels.

\section{Abbreviations}

FM: fish meal; SBM: soybean meal; FSBM: Shewanella sp. MR-7 fermented soybean meal; CDS: coding sequence; COG: Clusters of Orthologus Groups; KEGG: Kyoto Encyclopedia of Genes and Genomes; GO: gene ontology; ELISA: enzymelinked immunosorbent assay; TCA-N: trichloroacetic acid soluble nitrogen; ANFs: antinutritional factors; SR: survival rate; WGR: weight gain rate; SGR: specific growth rate; Fl: feed intake; FER: feed efficiency ratio; PER: protein efficiency ratio; ADC: apparent digestibility coefficients; qRT-PCR: quantitative real-time polymerase chain reaction; $\mathrm{VH}$ : villi height; $\mathrm{LD}$ : lumendiameter; $\mathrm{R}$ : villi height/ lumen diameter; TNF-a: tumor necrosis factor-a; IL-1 $\beta$ : interleukin-1 $\beta$; TGF- $\beta 1$ : transforming growth factor- $\beta 1$; MUC-2: mucin 2; ZO-1: zonula occluden-1; OTUs: operational taxonomic units; PCoA: principal coordinate analysis.

\section{Acknowledgements}

Not applicable.

\section{Authors' contributions}

$\mathrm{GH}, \mathrm{XW}$, and $\mathrm{KM}$ designed this study. XW, XP and $\mathrm{HZ}$ provided essentia reagents and materials. $C L$ and $B Z$ conducted the research, analysed the data, and wrote the manuscript. All authors read and approved the final manuscript.

\section{Funding}

This study was supported by the National Key R\&D Program of China (2018YFD0900400), National Natural Scientific Foundation of China grant (31772860), Aoshan Talents Cultivation Program Supported by Qingdao National Laboratory for marine science and technology (2017ASTCP-OS12), Fundamental Research Funds for the Central Universities (201822017) to GH, and China Agriculture Research System (CARS-47-G10) to KM.

\section{Availability of data and materials}

The strain Shewanella sp. MR-7 has been deposited in China General Microbiological Culture Collection Center (CGMCC) under collection number CGMCC 1.17098. The genome sequence data reported in this study are available in the China National Gene Bank (CNGB) Nucleotide Sequence Archive (CNSA: https://db.cngb.org/cnsa, accession number CNP0000499). The microbiome sequence data reported in this study have been deposited in the Genome Sequence Archive (Genomics, Proteomics \& Bioinformatics 2017) in BIG Data Center (Nucleic Acids Res 2018), Beijing Institute of Genomics (BIG), Chinese Academy of Sciences, under accession numbers PRJCA001060 that are publicly accessible at http://bigd.big.ac.cn/gsa.

\section{Ethics approval and consent to participate}

This study was performed in strict accordance with the recommendations in the Guide for the Institutional Animal Care and Use Commission (IACUC). The protocols were approved by the Committee on the Ethics of Animal Experiments of the Ocean University of China (Permit Number: 20150101).

\section{Consent for publication}

Not applicable.

\section{Competing interests}

The authors declare that they have no competing interests.

\section{Author details}

${ }^{1}$ Key Laboratory of Aquaculture Nutrition and Feed, Ministry of Agriculture, Ocean University of China, 5 Yushan Road, Qingdao 266003, People's Republic of China. ${ }^{2}$ Key Laboratory of Mariculture (Ministry of Education), Ocean University of China, Qingdao 266003, China. ${ }^{3}$ Laboratory for Marine Fisheries Science and Food Production Processes, Qingdao National Laboratory for Marine Science and Technology, Qingdao 266237, China. ${ }^{4}$ Institute of Plant Protection and Microbiology, Zhejiang Academy of Agricultural Sciences, Hangzhou 310021, People's Republic of China.

Received: 26 September 2019 Accepted: 5 December 2019

Published online: 16 December 2019

\section{References}

1. Nicholson JK, Holmes E, Kinross J, Burcelin R, Gibson G, et al. Host-gut microbiota metabolic interactions. Science. 2012:336:1262-7.

2. Hooper LV, Wong MH, Thelin A, Hansson L, Falk PC, et al. Molecular analysis of commensal host-microbial relations hips in the intestine. Science. 2001;291:881-4.

3. Huttenhower C, Gevers D, Knight R, Abubucker S, Badger JH, et al. Structure, function and diversity of the healthy human microbiome. Nature. 2012;486:207-14.

4. Cantarel BL, Lombard V, Henrissat B. Complex carbohydrate utilization by the healthy human microbiome. PLoS ONE. 2012;7:e28742.

5. Gorjifard S, Goldszmid RS. Microbiota-myeloid cell crosstalk beyond the gut. J Leukoc Biol. 2016;100:865-79.

6. Caesar R, Tremaroli V, Kovatcheva-Datchary P, Cani PD, Backhed F. Crosstalk between gut microbiota and dietary lipids aggravates WAT inflammation through TLR signaling. Cell Metab. 2015;22:658-68.

7. Usami M, Miyoshi M, Yamashita H. Gut microbiota and host metabolism in liver cirrhosis. World J Gastroenterol. 2015;21:11597-608.

8. Ussar S, Griffin NW, Bezy O, Fujisaka S, Vienberg S, et al. Interactions between gut microbiota, host genetics and diet modulate the predisposition to obesity and metabolic syndrome. Cell Metab. 2015;22:516-30.

9. Gatesoupe FJ. The use of probiotics in aquaculture. Aquaculture. 1999:180:147-65.

10. Hatje E, Neuman C, Stevenson H, Bowman JP, Katouli M. Population dynamics of Vibrio and Pseudomonas species isolated from farmed tasmanian Atlantic salmon (Salmo salar L.): a seasonal study. Microb Ecol. 2014;68:679-87.

11. Cahill MM. Bacterial flora of fishes: a review. Microb Ecol. 1990;19:21-41.

12. Egerton S, Culloty S, Whooley J, Stanton C, Ross RP. The gut microbiota of marine fish. Front Microbiol. 2018;9:873.

13. Clements KD, Angert ER, Montgomery WL, Choat JH. Intestinal microbiota in fishes: what's known and what's not. Mol Ecol. 2014;23:1891-8.

14. Clements KD, Raubenheimer D, Choat JH. Nutritional ecology of marine herbivorous fishes: ten years on. Funct Ecol. 2009;23:79-92.

15. Hardy RW. Utilization of plant proteins in fish diets: effects of global demand and supplies of fishmeal. Aquac Res. 2010;41:770-6.

16. Ding Z, Zhang Y, Ye J, Du Z, Kong Y. An evaluation of replacing fish meal with fermented soybean meal in the diet of Macrobrachium nipponense: growth, nonspecific immunity, and resistance to Aeromonas hydrophila. Fish Shellfish Immunol. 2015:44:295-301.

17. Tibaldi E, Hakim Y, Uni Z, Tulli F, de Francesco M, et al. Effects of the partial substitution of dietary fish meal by differently processed soybean meals on growth performance, nutrient digestibility and activity of intestinal brush border enzymes in the European sea bass (Dicentrarchus labrax). Aquaculture. 2006;261:182-93.

18. Gu M, Bai N, Zhang Y, Krogdahl A. Soybean meal induces enteritis in turbot Scophthalmus maximus at high supplementation levels. Aquaculture. 2016;464:286-95 
19. Francis G, Makkar HPS, Becker K. Antinutritional factors present in plantderived alternate fish feed ingredients and their effects in fish. Aquaculture. 2001;199:197-227.

20. Ray AK, Ghosh K, Ringo E. Enzyme-producing bacteria isolated from fish gut: a review. Aquac Nutr. 2012;18:465-92.

21. Liu Y, He G, Wang Q, Mai K, Xu W, Zhou H. Hydroxyproline supplementation on the performances of high plant protein source based diets in turbot (Scophthalmus maximus L.). Aquaculture. 2014;433:476-80.

22. Aliakbarpour HR, Chamani M, Rahimi G, et al. The Bacillus subtilis and lac tic acid bacteria probiotics influences intestinal mucin gene expression, histomorphology and growth performance in broilers. Asian Australas J Anim Sci. 2012;25:1285-93.

23. Nayak SK. Probiotics and immunity: a fish perspective. Fish Shellfish Immunol. 2010;29:2-14.

24. Cai YM, Benno Y, Nakase T, Oh TK. Specific probiotic characterization of Weissella hellenica DS-12 isolated from flounder intestine. J Gen Appl Microbiol. 1998:44:311-6.

25. Carnevali O, Zamponi MC, Sulpizio R, Rollo A, Nardi M, et al. Administration of probiotic strain to improve sea bream wellness during development. Aquac Int. 2004;12:377-86.

26. Nguyen TL, Park C-I, Kim D-H. Improved growth rate and disease resistance in olive flounder, Paralichthys olivaceus, by probiotic Lactococcus lactis WFLU12 isolated from wild marine fish. Aquaculture. 2017;471:113-20.

27. Anzai Y, Kim H, Park JY, Wakabayashi H, Oyaizu H. Phylogenetic affiliation of the pseudomonads based on $16 \mathrm{~S}$ rRNA sequence. Int J Syst Evol Microbiol. 2000;50:1563-89.

28. Li Y, Yang P, Zhang Y, Ai Q, Xu W, Zhang W, Zhang Y, Hu H, Liu J, Mai K. Effects of dietary glycinin on the growth performance, digestion, intestinal morphology and bacterial community of juvenile turbot, Scophthalmus maximus L. Aquaculture. 2017;479:125-33.

29. Yang P, Hu H, Liu Y, Li Y, Ai Q, Xu W, Zhang W, Zhang Y, Zhang Y, Mai K. Dietary stachyose altered the intestinal microbiota profile and improved the intestinal mucosal barrier function of juvenile turbot, Scophthalmus maximus L. Aquaculture. 2018;486:98-106.

30. Yoon JH, Yeo SH, Kim IG, Oh TK. Shewanella marisflavi sp nov and Shewanella aquimarina sp nov., slightly halophilic organisms isolated from sea water of the Yellow Sea in Korea. Int J Syst Evol Microbiol. 2004;54:2347-52.

31. Ivanova EP, Nedashkovskaya OI, Zhukova NV, Nicolau DV, Christen R, et al. Shewanella waksmanii sp nov., isolated from a sipuncula (Phascolosoma japonicum). Int J Syst Evol Microbiol. 2003;53:1471-7.

32. Ivanova EP, Nedashkovskaya OI, Sawabe T, Zhukova NV, Frolova GM, et al. Shewanella affinis sp nov., isolated from marine invertebrates. Int J Syst Evol Microbiol. 2004:54:1089-93.

33. Esakkiraj P, Immanuel G, Sowmya SM, lyapparaj P, Palavesam A. Evaluation of protease-producing ability of fish gut isolate Bacillus cereus for aqua feed. Food Bioprocess Technol. 2009;2:383-90.

34. Askarian F, Zhou Z, Olsen RE, Sperstad S, Ringo E. Culturable autochthonous gut bacteria in Atlantic salmon (Salmo salar L.) fed diets with or without chitin. Characterization by 165 rRNA gene sequencing, ability to produce enzymes and in vitro growth inhibition of four fish pathogens. Aquaculture. 2012;326:1-8.

35. Ghosh K, Sen SK, Ray AK. Characterization of bacilli isolated from gut of rohu, Labeo rohita, fingerlings and its significance in digestion. J Appl Aquac. 2002;12:33-42

36. Mukherjee R, Chakraborty R, Dutta A. Role of fermentation in improving nutritional quality of soybean meal - a review. Asian-Australas J Anim Sci. 2016;29:1523

37. Wang L, Zhou H, He R, Xu W, Mai K, et al. Effects of soybean meal fermentation by Lactobacillus plantarum P8 on growth, immune responses, and intestinal morphology in juvenile turbot (Scophthalmus maximus L.). Aquaculture. 2016:464:87-94.

38. Seo S-H, Cho S-J. Changes in allergenic and antinutritional protein profiles of soybean meal during solid-state fermentation with Bacillus subtilis. Lwt-Food Sci Technol. 2016;70:208-12.

39. Chou RL, Her BY, Su MS, Hwang G, Wu YH, et al. Substituting fish meal with soybean meal in diets of juvenile cobia Rachycentron canadum. Aquaculture. 2004;229:325-33.

40. Egounlety M, Aworh OC. Effect of soaking, dehulling, cooking and fermentation with Rhizopus oligosporus on the oligosaccharides, trypsin inhibitor, phytic acid and tannins of soybean (Glycine max Merr.), cowpea
(Vigna unguiculata L. Walp) and groundbean (Macrotyloma geocarpa Harms). J Food Eng. 2003;56:249-54.

41. Chi C-H, Cho S-J. Improvement of bioactivity of soybean meal by solidstate fermentation with Bacillus amyloliquefaciens versus Lactobacillus spp. and Saccharomyces cerevisiae. Lwt-Food Sci Technol. 2016;68:619-25.

42. Cervantes-Pahm SK, Stein HH. Ileal digestibility of amino acids in conventional, fermented, and enzyme-treated soybean meal and in soy protein isolate, fish meal, and casein fed to weanling pigs. J Anim Sci. 2010;88:2674-83.

43. Chen CC, Shih YC, Chiou PWS, Yu B. Evaluating nutritional quality of single stage- and two stage-fermented soybean meal. Asian-Australas J Anim Sci. 2010;23:598-606.

44. Peng M, Xu W, Ai Q, Mai K, Liufu Z, et al. Effects of nucleotide supplementation on growth, immune responses and intestinal morphology in juvenile turbot fed diets with graded levels of soybean meal (Scophthalmus maximus L.). Aquaculture. 2013;392:51-8.

45. Chen W, Ai Q, Mai K, Xu W, Liufu Z, et al. Effects of dietary soybean saponins on feed intake, growth performance, digestibility and intestinal structure in juvenile Japanese flounder (Paralichthys olivaceus). Aquaculture. 2011:318:95-100.

46. Yu DH, Gong SY, Lin YC, Yuan YC. Partial replacement of fish meal by several plant proteins with or without iron and lysine supplement in diets for juvenile Chinese sucker, Myxocyprinus asiaticus. Aquac Nutr. 2014;20:205-12.

47. Shiu YL, Hsieh SL, Guei WC, Tsai YT, Chiu CH, et al. Using Bacillus subtilis E20-fermented soybean meal as replacement for fish meal in the diet of orange-spotted grouper (Epinephelus coioides, Hamilton). Aquac Res. 2015;46:1403-16.

48. De Santis C, Bartie KL, Olsen RE, Taggart JB, Tocher DR. Nutrigenomic profiling of transcriptional processes affected in liver and distal intestine in response to a soybean meal-induced nutritional stress in Atlantic salmon (Salmo salar). Comp Biochem Physiol Part D Genomics Proteomics. 2015;15:1-11.

49. Grammes F, Reveco FE, Romarheim OH, Landsverk T, Mydland LT, et al. Candida utilis and Chlorella vulgaris counteract intestinal inflammation in Atlantic salmon (Salmo salar L.). PLoS ONE. 2013;8:e83213.

50. Tacchi L, Secombes CJ, Bickerdike R, Adler MA, Venegas C, et al. Transcriptomic and physiological responses to fishmeal substitution with plant proteins in formulated feed in farmed Atlantic salmon (Salmo salar). BMC Genomics. 2012;13:1-21.

51. Turner JR. Intestinal mucosal barrier function in health and disease. Nat Rev Immunol. 2009:9:799-809.

52. Kosinska A, Andlauer W. Modulation of tight junction integrity by food components. Food Res Int. 2013;54:951-60.

53. Kim YS, Ho SB. Intestinal goblet cells and mucins in health and disease: recent insights and progress. Curr Gastroenterol Rep. 2010;12:319-30.

54. Deplancke B, Gaskins HR. Microbial modulation of innate defense: goblet cells and the intestinal mucus layer. Am J Clin Nutr. 2001;73:1131S-41S.

55. Ahn DH, Crawley SC, Hokari R, Kato S, Yang SC, et al. TNF-alpha activates MUC2 transcription via NF-kappaB but inhibits via JNK activation. Cell Physiol Biochem. 2005;15:29-40.

56. Jiang W-D, Hu K, Zhang J-X, Liu Y, Jiang J, Wu P, Zhao J, Kuang S-Y, Tang $L$, Tang W-N, et al. Soyabean glycinin depresses intestinal growth and function in juvenile Jian carp (Cyprinus carpio var Jian): protective effects of glutamine. Br J Nutr. 2015;114:1569-83.

57. Zhang J-X, Guo L-Y, Feng L, Jiang W-D, Kuang S-Y, Liu Y, Hu K, Jiang J, Li S-H, Tang L, Zhou X-Q. Soybean beta-conglycinin induces inflammation and oxidation and causes dysfunction of intestinal digestion and absorption in fish. PLoS ONE. 2013;8:e58115.

58. Gu M, Jia Q, Zhang Z, Bai N, Xu X, Xu B. Soya-saponins induce intestinal inflammation and barrier dysfunction in juvenile turbot (Scophthalmus maximus). Fish Shellfish Immunol. 2018;77:264-72.

59. Belkaid $Y$, Hand TW. Role of the microbiota in immunity and inflammation. Cell. 2014;157:121-41.

60. Gomez GD, Balcazar JL. A review on the interactions between gut microbiota and innate immunity of fish. FEMS Immunol Med Microbiol. 2008;52:145-54.

61. Luis Balcazar J, Decamp O, Vendrell D, De Blas I, Ruiz-Zarzuela I. Health and nutritional properties of probiotics in fish and shellfish. Microb Ecol Health Dis. 2006;18:65-70. 
62. Xavier RJ, Podolsky DK. Unravelling the pathogenesis of inflammatory bowel disease. Nature. 2007;448:427-34.

63. Blumberg R, Powrie F. Microbiota, disease, and back to health: a metastable journey. Sci Transl Med. 2012;4:137

64. Xing M, Hou Z, Yuan J, Liu Y, Qu Y, et al. Taxonomic and functional metagenomic profiling of gastrointestinal tract microbiome of the farmed adult turbot (Scophthalmus maximus). FEMS Microbiol Ecol. 2013;86:432-43.

65. Bai N, Gu M, Xu X, Xu B, Krogdahl A. Protective effects of mannan oligosaccharides on turbot Scophthalmus maximus suffering from soy enteropathy. Aquaculture. 2017;476:141-51.

66. Gajardo K, Rodiles A, Kortner TM, Krogdahl A, Bakke AM, et al. A highresolution map of the gut microbiota in Atlantic salmon (Salmo salar): a basis for comparative gut microbial research. Sci Rep. 2016;6:30893.

67. Apper E, Weissman D, Respondek F, Guyonvarch A, Baron F, et al. Hydrolysed wheat gluten as part of a diet based on animal and plant proteins supports good growth performance of Asian seabass (Lates calcarifer) without impairing intestinal morphology or microbiota. Aquaculture. 2016:453:40-8.

68. Elinav E, Strowig T, Kau AL, Henao-Mejia J, Thaiss CA, et al. NLRP6 inflammasome regulates colonic microbial ecology and risk for colitis. Cell. 2011;145:745-57.

69. Hirota SA, Ng J, Lueng A, Khajah M, Parhar K, et al. NLRP3 inflammasome plays a key role in the regulation of intestinal homeostasis. Inflamm Bowel Dis. 2011;17:1359-72

70. Soccol CR, de Souza Vandenberghe LP, Spier MR, Pedroni Medeiros AB, Yamaguishi CT, et al. The potential of probiotics: a review. Food Technol Biotechnol. 2010;48:413-34.

71. Carla Piazzon M, Alvar Calduch-Giner J, Fouz B, Estensoro I, Simo-Mirabet P, et al. Under control: how a dietary additive can restore the gut microbiome and proteomic profile, and improve disease resilience in a marine teleostean fish fed vegetable diets. Microbiome. 2017;5:164.

72. Liu CH, Chiu CS, Ho PL, Wang SW. Improvement in the growth performance of white shrimp, Litopenaeus vannamei, by a proteaseproducing probiotic, Bacillus subtilis E20, from natto. J Appl Microbiol. 2009;107:1031-41.

73. Shaheen M, Shah AA, Hameed A, Hasan F. Influence of culture conditions on production and activity of protease from Bacillus subtilis BS1. Pak J Bot. 2008;40:2161-9.

74. Okutucu B, Dincer A, Habib O, Zihnioglu F. Comparison of five methods for determination of total plasma protein concentration. J Biochem Biophys Method. 2007:70:709-11.

75. Grant JR, Stothard P. The CGView Server: a comparative genomics tool for circular genomes. Nucleic Acids Res. 2008;36:W181-4.

76. Delcher AL, Bratke KA, Powers EC, Salzberg SL. Identifying bacterial genes and endosymbiont DNA with Glimmer. Bioinformatics. 2007:23:673-9.

77. Lowe TM, Eddy SR. tRNAscan-SE: a program for improved detection of transfer RNA genes in genomic sequence. Nucleic Acids Res. 1997:25:955-64
78. Lagesen $\mathrm{K}$, Hallin $\mathrm{P}$, Rodland EA, Staerfeldt $\mathrm{H}-\mathrm{H}$, Rognes T, et al. RNAmmer: consistent and rapid annotation of ribosomal RNA genes. Nucleic Acids Res. 2007:35:3100-8.

79. Birkeland SE, Stepaniak L, Sørhaug T. Quantitative studies of heat-stable proteinase from Pseudomonas fluorescens P1 by the enzyme-linked immunosorbent assay. Appl Environ Microbiol. 1985;49:382-7.

80. Association of Official Analytical Chemists (AOAC). Official methods of analysis of official analytical chemists international. 16th ed. Arlington: Association of Official Analytical Chemists; 1995.

81. Wang Y, Liu XT, Wang HL, Li DF, Piao XS, et al. Optimization of processing conditions for solid-state fermented soybean meal and its effects on growth performance and nutrient digestibility of weanling pigs. Livest Sci. 2014;170:91-9.

82. Dai $\mathrm{C}, \mathrm{Ma} \mathrm{H}$, He R, Huang L, Zhu S, et al. Improvement of nutritional value and bioactivity of soybean meal by solid-state fermentation with Bacillus subtilis. Lwt-Food Sci Technol. 2017:86:1-7.

83. Medeiros S, Xie J, Dyce PW, Cai HY, DeLange K, et al. Isolation of bacteria from fermented food and grass carp intestine and their efficiencies in improving nutrient value of soybean meal in solid state fermentation. J Anim Sci Biotechnol. 2018:9:29.

84. Cheng Z, Ai Q, Mai K, Xu W, Ma H, et al. Effects of dietary canola meal on growth performance, digestion and metabolism of Japanese seabass, Lateolabraxjaponicus. Aquaculture. 2010;305:102-8.

85. Li Z-H, Li P, Shi Z-C. Molecular responses in digestive tract of juvenile common carp after chronic exposure to sublethal tributyltin. Ecotox Environ Safet. 2014;109:10-4.

86. Livak KJ, Schmittgen TD. Analysis of relative gene expression data using realtime quantitative PCR and the $2^{-\triangle \Delta C T}$ method. Methods. 2001:25:402-8.

87. Martin M. Cutadapt removes adapter sequences from high-throughput sequencing reads. Emb J. 2011:17:10-2.

88. Quast C, Pruesse E, Yilmaz P, Gerken J, Schweer T, et al. The SILVA ribosomal RNA gene database project: improved data processing and webbased tools. Nucleic Acids Res. 2013;41:D590-6.

89. Edgar RC, Haas BJ, Clemente JC, Quince C, Knight R. UCHIME improves sensitivity and speed of chimera detection. Bioinformatics. 2011;27:2194-200.

90. Haas BJ, Gevers D, Earl AM, Feldgarden M, Ward DV, et al. Chimeric 16 S rRNA sequence formation and detection in Sanger and 454-pyrosequenced PCR amplicons. Genome Res. 2011:21:494-504.

91. Edgar RC. UPARSE: highly accurate OTU sequences from microbial amplicon reads. Nat Methods. 2013:10:996.

92. Edgar RC. MUSCLE: multiple sequence alignment with high accuracy and high throughput. Nucleic Acids Res. 2004;32:1792-7.

\section{Publisher's Note}

Springer Nature remains neutral with regard to jurisdictional claims in published maps and institutional affiliations.
Ready to submit your research? Choose BMC and benefit from:

- fast, convenient online submission

- thorough peer review by experienced researchers in your field

- rapid publication on acceptance

- support for research data, including large and complex data types

- gold Open Access which fosters wider collaboration and increased citations

- maximum visibility for your research: over 100M website views per year

At BMC, research is always in progress.

Learn more biomedcentral.com/submissions 